\title{
Incremental Usefulness of the Parent-only Balance Sheet to Debt Holders: Evidence from Banks
}

\author{
Jennifer Wu Tucker \\ Fisher School of Accounting \\ University of Florida \\ (352) 273-0214 (office) \\ jenny.tucker@warrington.ufl.edu \\ Ying Zhou \\ School of Business \\ University of Connecticut \\ (860) 486-3019 (office) \\ yzhou@business.uconn.edu \\ Jigao Zhu \\ College of Business \\ University of International Business and Economics (UIBE) \\ Beijing, China 100029 \\ zhujigao@uibe.edu.cn
}

July 2020

We thank Mark Bradshaw, Larry DiMatteo (professor of law), Mark Flannery, Paul Griffin, Ilan Guttman, Pat Hopkins, Jingzhi Huang, Seil Kim, Todd Kravet, Jongsub Lee, Leming Lin, Frank Murphy, Stephen Ryan, Katherine Schipper, Syrena Shirley, Danny Sokol (professor of law), Paul Taylor, Guner Velioglu, David Weber, Philip Wang, Michael Willenborg, Biqin Xie, Sunny Yang, Mark Zakota, Xinmin Zhang, Wentong Zheng (professor of law), and workshop participants of the University of California at Davis, University of Connecticut, New York University, Penn State University, and National Taiwan University. We thank Jeffery Piao for capable research assistance. 


\title{
Incremental Usefulness of the Parent-only Balance Sheet to Debt Holders: Evidence from Banks
}

\begin{abstract}
Under U.S. GAAP, general-purpose financial statements are prepared for a consolidated reporting entity, aggregating the information of a parent company and any subsidiaries over which the parent has control. In this study, we examine whether the parent-only balance sheet is useful for assessing the parent's credit risk beyond the consolidated balance sheet. We obtain evidence from bank holding companies, which provide parent-only financial statements to comply with bank regulations. We find that the parent-only leverage ratio is positively associated with the premium of credit default swap (CDS) - the price of protection against the parent's default risk - after controlling for the consolidated leverage ratio. We also test the relation between the parent-only leverage ratio and the pricing of credit risk in a substantially larger sample of banks with bond issuances and draw a similar conclusion. Our evidence raises the question of whether debt holders' information needs are better served if consolidated financial statements are supplemented with parent-only financial statements.
\end{abstract}

Keywords: Consolidation, parent-only, disaggregation, debt, banks.

Data availability: All data are available from identified public sources. 


\section{Introduction}

While most capital-market accounting research examines the role of accounting information in the equity market, the debt market is substantially larger than the equity market (Armstrong, Guay, and Weber 2010, p.212; Givoly, Hayn, and Katz 2017). During 2009-2014, two-thirds of the public offerings in the U.S. were debt (SEC 2015). In 2014, for example, the dollar amount of funds raised from public debt was more than four times the amount raised from public equity. If private offerings are also considered, the landscape is even more lopsided: about $90 \%$ of the funds raised in the capital markets are in the form of debt (Gomes and Phillips 2012). Debt holders have a different payoff structure and, therefore, different information needs from equity shareholders. Debt holders are particularly interested in a firm's credit risk, which may affect the firm's ability to pay interests and repay the principal. An important question then arises: How does the current consolidated financial reporting model serve debt holders?

At least one in five U.S. publicly listed firms have controlling interests in subsidiaries and therefore must report consolidated financial statements under U.S. Generally Accepted Accounting Principles (GAAP). ${ }^{1}$ Some information is lost in the aggregation process of consolidation. Consolidated financial statements appear to focus more on a parent company's equity shareholders than on its debt holders. ${ }^{2}$ For example, the consolidated balance sheet separately reports the equity claims of the parent's shareholders and the aggregate claims of noncontrolling shareholders of the consolidated subsidiaries (referred to as "noncontrolling interests" or "minority interests"). This separation serves the parent's equity shareholders. In contrast, the consolidated balance sheet reports the total assets and total liabilities of the parent company and its consolidated subsidiaries as if the parent owns $100 \%$ of these subsidiaries. In other words, the consolidated balance sheet does not report what debt is the parent's responsibility separately from what

\footnotetext{
${ }^{1}$ The minority-interest variable in Compustat is positive for about $20 \%$ of U.S. firms, suggesting that at least $20 \%$ of firms report consolidated financial statements. Note that firms that own $100 \%$ of their subsidiaries report zero minority interests even though they consolidate these subsidiaries.

2 "Debt" is a subset of liabilities. In our study, debt includes loans, bonds, and capitalized lease liabilities and does not include accounts payables, pension liabilities, and deferred tax liabilities. The latter are less relevant to credit risk in debt markets because accounts payables are for transaction purposes, pension liabilities arise from labor contracts, and deferred asset liabilities are due to the timing differences between tax accounting and financial accounting (Rajan and Zingales 1995).
} 
debt is the consolidated subsidiaries' responsibility, nor does the consolidated balance sheet report what resources are available to repay the parent's debt separately from what resources are available to repay the consolidated subsidiaries' debt. The lack of these distinctions ill-serves the parent's debt holders. Some information useful to a parent's debt holders is lost during consolidation.

A parent and each of its consolidated subsidiaries are separate legal entities and each has its own limited liability. Debt contracts are written for legal entities to allow subsequent enforcements and dispute resolution. The consolidated reporting entity only exists for financial reporting purposes and is not necessarily a legal entity in and of itself. Piercing the corporate veil (PCV) would allow courts to disregard limited liability and impose the debt of subsidiaries on the parent company or the debt of the parent on subsidiaries, but PCV is rare for modern corporations in the U.S. (Belenzon, Lee, and Pataconi 2018). Unless PCV is invoked, a parent's debt holders cannot look to its subsidiary's assets for satisfaction of their claims until each and every creditor of the subsidiary has been provided for in full and the subsidiary is liquidated with the residual property distributed to the parent (Coquillette 1980).

In theory, private lenders have access to a borrowing firm's private information beyond consolidated financial statements. For example, private lenders may include disclosure covenants that require parent-only statements or consolidating financial statements (i.e., multiple columns showing the parent and major subsidiaries as well as the aggregated column) to be provided on a regular basis over the loan contract term (Carrizosa and Ryan 2017). This private access, however, is generally not available for public debt holders. Our study focuses on the information needs of public debt holders.

From an information economics perspective, the parent-only balance sheet-disaggregated information for the most important member of the consolidated reporting entity-may compensate for the information loss to debt holders occurred during consolidation and could thus be useful for assessing the parent's credit risk beyond the consolidated balance sheet. We refer to this argument as the "information loss argument."

Two mechanisms address public debt holders' information problem: (1) guarantees and (2) thirdparty credit ratings. Explicit guarantee agreements and implicit credit support between a parent and its 
subsidiaries can blur the legal boundaries between these separate entities. Credit rating agencies have access to additional corporate information beyond what is publicly available and may incorporate parent-only balance sheet information in their ratings, saving debt holders from having to analyze this information themselves. Thus, the parent-only balance sheet might not be incrementally useful for assessing the parent's credit risk beyond the consolidated balance sheet after credit ratings are accounted for. We refer to this reasoning as the "mechanism mitigation argument."

We empirically examine whether the parent-only balance sheet is incrementally useful for assessing the parent's credit risk beyond the consolidated balance sheet by using a sample of bank holding companies (hereinafter "banks"). Parent-only financial statements are voluntary and uncommon in the U.S. except for in the banking and insurance industries. In addition to filing consolidated financial statements to the Securities and Exchange Commission (SEC), banks are required by regulators to provide quarterly parentonly financial statements in the form of FR Y-9LP reports. These reports are made immediately available to the public. Data from banks would allow us to provide direct evidence on our research question, although our findings may not be generalizable to non-financial firms.

We use the financial leverage ratio to summarize key credit-risk information in the balance sheet. The ratio measures a firm's ability to honor its financial obligations given its resources and commonly serves as a main signal of credit risk for both financial and non-financial firms (Rajan and Zingales 1995). The higher the leverage ratio, the higher the credit risk. In particular, Blankespoor, Linsmeier, Petroni, and Shakespeare (2013) draw inferences about the usefulness of fair value vs. mixed-attribute-value measurements of financial instruments at banks by examining the associations between the leverage ratios calculated using these alternative measurements and bond spreads. ${ }^{3}$ We use a similar empirical strategy but focus on whether the leverage ratio calculated from the parent-only balance sheet has incremental

\footnotetext{
${ }^{3}$ This research design is similar to traditional value-relevance studies, in which researchers assess whether a type of information is useful to equity investors based on the association of that information with stock price or changes in stock price.
} 
information about credit risk beyond the consolidated leverage ratio, instead of focusing on which leverage ratio contains more information about credit risk.

To gauge the usefulness of the parent-only leverage ratio for assessing the parent's credit risk, we examine the pricing of the ratio in a credit default swap (CDS) contract that references the parent. A CDS contract is an insurance contract that protects the buyer, who is not required to hold the referenced company's debt, against the company's credit risk. In return for this protection, the buyer pays a fixed premium to the seller over the period of protection (maturity). CDS contracts can be traded on standardized terms subsequently over the counter, where new contracts with the same maturity and underlying may be initiated at the same time. The premium (also called "spread") of traded or new CDS contract with the same maturity and underlying changes daily reflects traders' updated assessments of the company's credit risk. As a pure credit-default instrument, the CDS premium is more responsive to credit-risk information than the pricing of other debt instruments (Callen, Livnat, and Segal 2009; Lee, Naranjo, and Velioglu 2018). Moreover, in the recent decade, CDS markets have become more active and liquid than bond markets (Das, Kalimipalli, and Nayak 2014), giving us additional reasons to use CDS in our primary analyses.

We examine whether the parent-only leverage ratio is positively associated with the CDS premium, for which the parent is the reference entity, after controlling for the consolidated leverage ratio. Under the information loss argument, a positive association is expected because a parent's debt holders are ultimately interested in the parent's balance sheet and would assess a higher credit risk if the parent is more leveraged. Under the mechanism mitigation argument, the consolidated balance sheet is sufficient, rendering the parent-only leverage ratio not incrementally useful.

We collect 932 bank-quarters with CDS coverage from 2000 to 2017. This sample includes relatively large firms in the banking industry. ${ }^{4}$ The median ratio of parent-only debt to consolidated debt is

\footnotetext{
${ }^{4}$ A downside of using CDS for pricing credit risk is that not every company with debt has a CDS market. However, companies with CDS are relatively large and account for the majority of market capitalizations. For example, our 2017 sample accounts for $61 \%$ of the total market capitalization of all U.S. public banks.
} 
0.19 and the median ratio of parent-only total assets to consolidated total assets is 0.16 , suggesting that parent-only balance sheets differ considerably from consolidated balance sheets.

Prior research uses a variety of methods to calculate leverage ratios. We use two methods that are most appropriate in our setting. In the first method, we divide debt (i.e., short- and long-term loans and bonds) by the sum of debt and shareholders' equity. The median of this leverage ratio is 0.26 for the parent and 0.64 for the consolidated reporting entity. In the second method, we divide debt by total assets. The median of this leverage ratio is 0.22 for both the parent and the consolidated reporting entity. Under both methods, some firms have higher parent-only leverage than consolidated leverage and others have higher consolidated leverage than parent-only leverage.

We find that the parent-only leverage ratio is positively associated with the CDS premium, which has been adjusted for the premium level of firms with similar credit ratings as in the use of market-adjusted stock returns in equity research, after we control for the consolidated leverage ratio. Our findings are similar when using either method to calculate the parent-only leverage ratio. The economic effect is significant. For example, if we increase the parent-only ratio, calculated by the second method, from the $25^{\text {th }}$ to $75^{\text {th }}$ percentile while holding all other independent variables constant, the CDS premium increases by $9.4 \%$. We then examine the effect of the change in parent-only leverage from the previous quarter to the current quarter on the change in CDS premium and draw similar inferences. These findings suggest that the parentonly balance sheet provides additional credit-risk information about the parent beyond the consolidated balance sheet and third-party credit ratings.

We also regress the CDS premium on either the parent-only leverage ratio or the consolidated leverage ratio separately and compare the relative explanatory power of the two non-nested models. We find that the parent-only leverage ratio, calculated using the second method (i.e. debt over total assets), has significantly greater explanatory power for the CDS premium than the consolidated leverage ratio calculated using the same method. The leverage ratios calculated using the first method (i.e., debt over the sum of debt and equity) for the parent-only and consolidated balance sheets exhibit similar explanatory 
power, though. Thus, there is some evidence that the parent-only balance sheet is more useful for providing credit risk information about the parent than the consolidated balance sheet.

In a supplementary analysis, we expand the sample by forgoing the requirement of CDS contracts and instead selecting banks with bond issuances during our sample period. We collect 3,569 bond issuances, a sample significantly larger and much more representative of public banks than our CDS sample. We follow the research design of Bharath, Sunder, and Sunder (2008) and Blankespoor et al. (2013) and find that the parent-only leverage ratio is significantly incrementally associated with bond spreads at issuance. This result corroborates our primary findings drawn from the CDS sample, mitigating the concern that our CDS sample is too small for the findings to be generalized to all banks.

Our study makes two contributions to the accounting literature. First, our study may revive a debate on the consolidated financial reporting model, which has been embraced by U.S. regulators for decades. Even though this reporting model can curb a parent company from keeping borrowings that are strategically obtained through its subsidiaries off its balance sheet, some information beneficial to debt holders is lost during consolidation. According to Pacter (1993), the Robert Morris Associates (RMA) — an association of 15,000 loan and credit officers from more than 3,000 banking associations in the U.S. and Canada—voiced strong concern about the information loss of consolidation and proposed that firms provide consolidating instead of consolidated financial statements. Francis (1986) echoes this concern. Using the final year when both statements were still available for some U.S. firms, he finds that the debt-related ratios calculated from consolidated vs. parent-only statements are quite different and that both types of ratios are used in debt covenants.

On the public availability of parent-only financial statements, the U.S. is an exception among major economies. Laws in the U.K., Germany, and France require the disclosure of parent-only statements. Through their countries' financial reporting regulators, Australia and China make similar requirements. Our findings raise the question of whether debt holders' information needs are better served if consolidated financial statements are supplemented with parent-only financial statements. We hope that our study will draw the attention of regulators, investors, and academics. 
Our study is closely related to Beaver, Cascino, Correia, and McNichols (2018). Using data from 117 countries, Beaver et al. find that a subsidiary's financial information improves the bankruptcy prediction of the parent company beyond the parent's financials and that a parent's financial information improves the bankruptcy prediction of a subsidiary beyond the subsidiary's financials. The explanation for their findings is that the potential support among the members of a business group represents an off-balance sheet asset for the receiving member and an off-balance sheet liability for the member offering support. In Section 9 of their paper, the authors replace bankruptcy occurrence with the CDS premium as the dependent variable and find consistent evidence (with results tabulated in Table OA-8 of their online appendix). Like Beaver et al., we highlight the importance of financial information about an individual member within a business group and question whether consolidated financial statements fully subsume the credit-relevant information of the members.

Our study distinguishes itself from Beaver et al. (2018) in two respects. First, we ask different research questions. We investigate whether the parent-only balance sheet provides incremental credit-risk information about the parent beyond the consolidated balance sheet. In contrast, Beaver et al. investigate whether the financial information of one member of a business group is useful for bankruptcy predictions of another member beyond the latter's financial information (which is not the consolidated information). Therefore, our findings cannot be inferred from theirs. Second, Beaver et al. conduct cross-country analyses using all industries, with financial institutions accounting for $41.2 \%$ of their parent firms, whereas we use a homogenous industry within a single country. This research design difference means that our study might be subjected to fewer omitted correlated variable problems than their study, but also less generalizable than theirs. Because of these differences, we believe that our study importantly complements Beaver et al.

The second contribution of our study is to extend the literature of financial reporting disaggregation. From an information economics perspective, disaggregated information is valuable to investors as long as information overload is avoidable. Prior research has examined segment reporting (Berger and Hann 2003), which is disaggregation of a firm's line of operations, and the reporting of earnings components (Lipe 1986; Ohlson and Penman 1992). Providing parent-only statements in addition to consolidated statements is 
disaggregation of the consolidated reporting entity into its legal entities, with the parent being the most important legal entity. Our evidence suggests that such disaggregation is valuable to debt holders.

\section{Background and Hypothesis Development}

2.1 The consolidated financial reporting model

Consolidated financial statements are nowadays customary in almost all major economies, but the history and role of consolidated statements vary. In the U.S., consolidated statements have been used as a substitute for parent company reports since the early 1900s (Walker 1976). The official requirement for consolidated financial statements began with Accounting Research Bulletin 51 "Consolidated Financial Statements," which took effect in August 1959. The standard requires that a parent company consolidate all subsidiaries over which it has control as if "the group were a single company with one or more branches or divisions." The exceptions to consolidation are subsidiaries in different businesses than the main operations of the parent (e.g., the finance arm) or subsidiaries subject to extreme uncertainty of whether the majority owner can exercise control (e.g., foreign subsidiaries). These exceptions appear to have been used by companies as loopholes to camouflage debt by borrowing through their unconsolidated subsidiaries (Weiss 1985). Statement of Financial Accounting Standard (SFAS) 94, "Consolidation of All Majorityowned Subsidiaries," effective in October 1987, closed these loopholes by requiring consolidation of majority-owned subsidiaries without exceptions.

The most recent rule guiding consolidated financial statements was SFAS 160, "Noncontrolling Interests in Consolidated Financial Statements," effective for fiscal periods ending after December 15, 2008. The standard removes companies' flexibility in presenting minority interest in the balance sheetpreviously, minority interest could appear either in the liability or equity section, but now it must appear in the equity section — and requires the proportion of aggregate earnings attributable to minority shareholders to be presented separately in the income statement. ${ }^{5}$ The standard allows parent-only statements to

\footnotetext{
${ }^{5}$ Before SFAS 160, net income attributable to minority interest was typically reported as an expense or other deduction in arriving at net income attributable to the parent and was often presented in combination with other financial statement amounts.
} 
accompany consolidated statements if necessary, but clearly states: "However, consolidated financial statements are the general-purpose financial statements of a parent having one or more subsidiaries; thus, parent-company financial statements are not a valid substitute for consolidated financial statements." As a result, parent-only statements are uncommon for U.S. companies.

Corporations in major economies other than the U.S. and Canada are required to provide their own financial statements, regardless of whether they are members of a consolidated reporting entity. In these economies, whether consolidated financial statements are additionally required depends on the legal form and the size of a company (Minnis and Shroff 2017). Consolidated statements have been introduced to these economies due to the influence of financial reporting in the U.S. as well as the influence of international standard setters. The latter have been requiring only consolidated financial statements since 1974 through International Accounting Standard 3, "Consolidated Financial Statements," which was updated by International Financial Reporting Standards (IFRS) No. 10 in 2013. Consolidated statements were introduced in the U.K., Australia, and Japan to supplement parent companies' reports (Walker 1976; Francis 1986; Herrmann, Inoue, and Thomas 2001). Even after the adoption of IFRS by the European Union and Australia in 2005, these countries still require parent-only statements in addition to consolidated statements. The U.S. and Canada are the only two major economies in which parent-only statements are not commonly available. $^{6}$

\subsection{Hypothesis development}

Limited liability is one of the best legal advantages of using the corporate form to conduct business. According to Belenzon et al. $(2018, p .2)$, scholars in the early $20^{\text {th }}$ century lauded the limited liability corporation as "the greatest single discovery of modern time" and "the most effective legal invention made in the $19^{\text {th }}$ century." Debt holders enter into contracts with a specific legal entity. As separate legal entities, a parent company and its subsidiaries are each responsible only for their own debt even though they are all

\footnotetext{
${ }^{6}$ In China, the Securities Regulatory Commission issued a regulation in 1994 requiring a publicly listed company to report consolidated financial statements if it owns more than $50 \%$ of its subsidiaries. Since the convergence to IFRS in 2007, consolidated financial statements have been the primary financial statements in China.
} 
part of one business group. Thus, firms may use incorporation and limited liability to "compartmentalize liabilities, thus preventing risks from spreading across business units" (Belenzon et al., p.2).

An exception to limited liability is PCV. The PCV doctrine is vague and discretionary, and the U.S. is in the middle of the spectrum regarding how often PCV is invoked, with the U.K. invoking it the least often and Germany the most often (Belenzon et al. 2018). In the U.S., PCV for parent-subsidiary piercing is unsuccessful unless there are illegitimate activities that abuse the rationales of incorporation or the parent has complete control of a subsidiary's day-to-day decision making (Belenzon et al.). Thus, the financial statements of a specific firm contain information important to its debt holders and its balance sheet is necessary for debt holders to evaluate the firm's ability to meet its obligations (Walker 1976).

The U.S. accounting standard setters seem to have focused on the question of whether consolidated or parent-only financial statements are superior-a question of substitution. They might have ignored the question of supplementation — whether consolidated statements should be presented alone or supplemented with parent-only statements. Consolidation involves a process of aggregation, where the financial statements of the parent and its subsidiaries are combined line by line and then intercompany transactions are eliminated. The consolidated balance sheet reports all the liabilities and assets of the parent and its consolidated subsidiaries as if they were one company. There is no way for the parent's debt holders to know which liabilities and assets are the parent's and which are the subsidiaries', even though such information is useful for assessing the parent's credit risk.

Academics have voiced the concern that consolidated statements do not provide sufficient information to debt holders (Walker 1976; Francis 1986). More importantly, two major groups of financial statement users have argued for consolidating instead of consolidated financial statements. The predecessor of the Chartered Financial Analyst Institute - the Association of Investment Management and Researchstated this position in its October 1992 report and lamented the "concomitant loss of detailed information about an economic enterprise's constituent corporate entity components" (Pacter 1993, p.97). In response to the FASB's consolidated financial reporting model, the RMA stated in a comment letter on July 15, 1992 that lenders desired consolidating financial statements so that they had financial information about the 
specific borrowing units. The association argued that lenders needed consolidated financial statements to have a view of the economic entity as a whole and needed entity-separate financial statements to evaluate the array and hierarchy of claims against an entity's economic resources (Pacter 1993).

From an information economics perspective, debt holders cannot be worse off with more information. If the parent-only financial statements provide new information, debt holders can update their risk assessments and make better decisions. If the parent-only statements do not provide new information, debt holders can simply discard them. ${ }^{7}$ On the supply side, the accounting system of a parent company should have all the information available for preparing parent-only statements and thus the direct disclosure cost is nil.

The existence of two mitigating mechanisms may render parent-only financial statements unnecessary and not incrementally useful for assessing the parent's credit risk. The first mechanism is guarantees between the legal entities within a consolidated reporting entity. A parent may guarantee a subsidiary's borrowings from unaffiliated parties (“downstream guarantee”). In this case, the subsidiary's debt becomes the parent's contingent liability if the subsidiary fails to make payments. ${ }^{8}$ A subsidiary may also guarantee the parent's debt ("upstream guarantee"). In this case, the subsidiary's assets could be used to satisfy the parent's debt holder's claims if the parent fails to do so. The guarantee mechanism may blur the legal boundaries between the parent and its subsidiaries and thus mitigate the parent's debt holders' information loss due to consolidation.

\footnotetext{
${ }^{7}$ From a psychological perspective, more information may result in information overload for users, who have limited processing ability and attention. Because the issue here is whether to additionally provide the parent company's financial statements, not whether to add separate financial statements of the parent and all its consolidated subsidiaries, we believe that information overload is unlikely to be a serious concern.

${ }^{8}$ FASB interpretation (FIN) No. 45, "Guarantor's Accounting and Disclosure Requirements for Guarantees," updates FASB No. 5, "Accounting for Contingencies." FIN 45 requires that at the inception of a guarantee, a guarantor must recognize the fair value of its obligation arising from issued or modified guarantees after December 31, 2012. One exception to the recognition rule is a parent's guarantee of a subsidiary's debt to a third party and a subsidiary's guarantee of debt owed to a third party by either its parent or a fellow subsidiary of its parent. Therefore, formal guarantees between a parent and its subsidiaries are only disclosed in the notes that accompany financial statements.
} 
However, the extent to which the guarantee mechanism mitigates information loss is uncertain. Formal guarantee agreements between the parent and its subsidiaries may not be prevalent. ${ }^{9}$ This is evidenced by the common practice of informal guarantees in the form of credit support. Lawyers of both a parent and its debt holders often carefully and painstakingly draft comfort letters (also called "comfort instruments") to avoid incurring a formal debt guarantee (DiMatteo and Sacasas 1995). Even in the bestcase scenario, when the parent owns $100 \%$ of all its consolidated subsidiaries and downstream and upstream full guarantees exist between the members of the consolidated reporting entity, the actual return to debt holders is still affected by the sequence in which the parent and its subsidiaries enter bankruptcy (Walker 1976). ${ }^{10}$

The second mechanism that mitigates the parent's debt holders' information loss is other sources of information, especially third-party credit ratings. Credit-rating agencies have special access to firms and may request parent-only statements for their credit-risk assessments. For example, the Dominion Bond Rating Service (DBRS) - the world's fourth-largest credit rating agency and one of the 10 rating agencies registered with the SEC — wrote in its rating manual for parent companies, "While consolidated statements can have value, DBRS typically finds that an analysis of the non-consolidated parent company statements is important, as it is important to understand the levels of debt, cash, and goodwill that exist at the parent company itself." If information in parent-only statements is fully incorporated in credit ratings, debt holders may not need to examine parent-only statements themselves and thus these statements would have no incremental value to market participants in assessing the parent's credit risk.

The reduction of information loss through credit rating agencies might be limited, though, for three reasons. First, credit ratings are coarse (e.g., S\&P provides only 13 grades) and may not be sufficient statistics of the information that rating agencies glean from parent-only statements. Second, the existence of minority interest presents challenges and uncertainties for rating agencies. Rating agencies typically start

\footnotetext{
${ }^{9}$ For example, Francis (1986) reports that $66 \%$ of his sample firms do not guarantee their subsidiaries' debt. We handcheck 15 banks randomly selected from our sample and find the disclosure of a parent's guarantees of its subsidiaries' debt by only six banks in the $10-\mathrm{K}$ or $10-\mathrm{Q}$ reports.

${ }^{10}$ Walker (1976, pp.110-112) provides two excellent examples to illustrate this point.
} 
with rating the senior unsecured debt of the parent assuming (1) this is the only class of debt, (2) all debt of the consolidated corporation is issued by the parent and guaranteed by all the subsidiaries, and (3) all domestic and foreign assets of the consolidated reporting entity are available to service that debt (Morningstar 2015). Corporate governance plays an important role in sorting out the conflict of interests between a parent and the minority shareholders of its subsidiaries. Rating agencies may not be able to predict how such a conflict will be resolved. ${ }^{11}$ Last, credit rating agencies may have their own conflicts of interests when rating companies, which pay for such service, and produce biased ratings (Bar-Isaac and Shapiro 2011; Jiang, Stanford, and Xie 2012; Kedia, Rajgopal, and Zhou 2014).

In sum, on the one hand, under the information loss argument, parent-only statements are expected to provide useful information to the parent's debt holders incremental to what they can learn from consolidated statements. On the other hand, the guarantee and credit-rating mechanisms may mitigate the information loss of debt holders. Whether parent-only statements provide useful information for assessing the parent's credit risk beyond consolidated statements is an empirical question.

Among the financial statements, we focus on the balance sheet because it is most relevant to creditors. We state our hypothesis in the null form as follows:

Hypothesis: The parent-only balance sheet is not useful for assessing the parent's credit risk beyond the consolidated balance sheet.

\section{Research Design}

\subsection{Identifying sample firms}

To test our hypotheses, we need sample firms that provide both consolidated and parent-only balance sheets. Since 1987, parent-only statements have become uncommon in the U.S. except for the banking and insurance industries. The Federal Reserve requires large banks to file quarterly parent-only

\footnotetext{
${ }^{11}$ For example, DBRS expresses the concern that minority interest could be a problem in rating the parent company because the parent company no longer fully controls the cash flows of the subsidiary.
} 
financial statements in FR Y-9LP reports. ${ }^{12}$ Each subsidiary of an insurance company is required to file an annual report with the National Association of Insurance Commissioners under Statutory Accounting Principles (which is different from U.S. GAAP). We choose banks as our sample over insurance companies because banks are relatively homogenous and represent a crucial sector of the U.S. economy.

\subsection{Summarizing balance-sheet credit-risk information}

The leverage ratio measures the level of debt relative to other capital or total capital and is the most important signal for gauging a firm's credit risk (Rajan and Zingales 1995). Following Blankespoor et al. (2013), who also examine banks, we use the leverage ratio to summarize the credit-risk information in banks' balance sheets.

We use two methods to calculate leverage ratios. ${ }^{13}$ Our first is the primary method used by Rajan and Zingales (1995) and Zhang, Zhou, and Zhu (2009), and we refer to the measure as Lev1. The numerator of this ratio is a firm's total debt, which is the sum of short- and long-term debt (e.g., loans and bonds); the denominator is the sum of total debt and the book value of shareholders' equity. ${ }^{14} \mathrm{We}$ do not include deposits and repos in debt because they are uncommon for bank holding companies and because most of the deposits in commercial-bank subsidiaries are insured by the FDIC while a repo lender has a collateral claim on the repo-ed asset. The second method for calculating leverage, used by Graham, Li, and Qiu (2008), keeps the same numerator as Levl but uses total assets as the denominator. We refer to this measure as Lev2.

\footnotetext{
${ }^{12}$ Small banks file parent-only statements in FR Y-9SP reports. The cutoff for large vs. small banks before March 2006 was consolidated total assets of $\$ 150$ million. The cutoff was increased to $\$ 500$ million, $\$ 1$ billion, and $\$ 3$ billion in March 2006, March 2015, and September 2018, respectively.

${ }^{13}$ Tier 1 risk-based capital ratio can be considered another leverage measure. In an untabulated analysis, we replace the consolidated leverage ratio with 1 minus Tier 1 capital ratio and find similar results for the parent-only leverage.

${ }^{14}$ Rajan and Zingales (1995) also calculate a leverage measure by replacing the book value of equity in Levl with the market value of equity. We do not use this market-based measure to avoid the effect of stock price volatility during the financial crisis.
} 
We calculate leverage ratios based on the parent-only balance sheet and refer to the variables under the two methods as PLev1 and PLev2. ${ }^{15}$ We calculate leverage ratios based on the consolidated balance sheet and refer to the variables as CLev1 and CLev2. Appendix 1 provides detailed variable definitions. Although we intend to measure PLev1 and CLev1 in parallel and measure PLev2 and CLev2 in parallel, the members of each pair are not exactly comparable because parent-only balance sheets follow categorizations specified by bank regulators, whereas banks have flexibility in presenting their line items in consolidated balance sheets filed to the SEC. ${ }^{16}$ Because of the comparability issue of PLev1 and CLev1 and of PLev2 and CLev2, each leverage ratio is best viewed as a ratio that summarizes the credit-risk information contained in the corresponding balance sheet as presented. In other words, they are the leverage ratios that holders of senior unsecured debt would typically use when presented with the balance sheet.

\subsection{The dependent variable}

Earlier bank research uses bond spreads as a proxy for the price that debt holders charge for bearing credit risk (Flannery and Sorescu 1996; Krishnan, Ritchken, and Thomson 2005). In the past decade, the growth of CDS markets and the availability of CDS data have allowed researchers to better measure the price of credit risk (Callen et al. 2009; Oehmke and Zawadowski 2017). CDS contracts are created to keep track of credit risk and traded on standardized terms (Zhang et al. 2009). The CDS premium tends to respond more quickly to changes in credit risk than bond spread (Lee et al. 2018). Moreover, CDS markets have fewer trading frictions than bond markets and as CDS markets grew, institutional investors migrated to CDS markets and as a result bond markets became less active and less liquid (Das et al. 2014). Thus, in our primary analyses we use the CDS premium to proxy for the price of bearing credit risk.

\footnotetext{
${ }^{15}$ One issue in our leverage calculations is the parent's debt owed to its subsidiaries. In tabulated analyses, we do not count this item in the parent's debt. In untabulated analyses, we find similar results if we add this item to the parent's equity.

${ }^{16}$ Banks file consolidated financial statements in FR Y-9C reports to the Federal Reserve. We do not calculate the consolidated leverage ratio based on FR Y-9C reports because their category "Other borrowed money" includes both items that we need (e.g., capitalized lease obligations) and items that we do not want (e.g., non-debt liabilities).
} 
A CDS contract is an insurance contract against the risk associated with credit-related events of a company and includes four main features. The reference entity is the company whose credit events are referred to in the contract and is the parent company in our setting. Credit events include failures to pay, bankruptcy, and restructuring. Before the CDS Big Bang on April 8, 2009, CDS contracts with modified restructuring (MR) clauses were most popularly traded in the U.S. Since the Big Bang, CDS contracts with no restructuring (XR) clauses are most popularly traded in the U.S. The deliverable obligations are the exact debt covered by the insurance and whose notional amount is supposed to be paid to the contract buyer in the case of a credit event. The vast majority of deliverable obligations for CDS contracts are senior unsecured debt. Maturity is the length of the insurance protection period. The most liquid maturity of CDS contracts is five years.

A CDS premium is stated in basis points per $\$ 100$ notional amount of the deliverable obligations. All CDS contracts are traded over the counter, with actual transaction prices unobservable. The information to which researchers have access is market makers' quotes of CDS premium compiled by data providers. We use the most liquid type of CDS contracts-5-year, senior unsecured debt, and MR or XR clauses. For a bank-quarter, we define $C D S P$ as the natural logarithm of the CDS premium on the first trading day after the due date of the YR F-9LP report.

Following Lee et al. (2018), we subtract a benchmark from CDSP to remove the market factor and incorporate the credit-risk information reported by credit rating agencies. For each bank-quarter, we identify in Compustat all U.S. firms with the same S\&P credit rating as the sample (parent) firm by the end of the quarter. We calculate the benchmark as the natural logarithm of the median premium of CDS contracts on the same day as $C D S P$ that use these firms as the reference entities and have similar features as the sample firm's CDS. We refer to the benchmark-adjusted variable as $C D S P_{a d j}$. An analogy of this variable is the market-adjusted or size-adjusted returns in equity market research. 


\subsection{Empirical model}

Our empirical model to test the hypothesis largely follows the baseline levels regression of Callen et al. (2009). The empirical framework is analogous to that of value relevance research and is also used by Blankespoor et al. (2013) even though their dependent variable is bond spreads. We augment the model with the bank-specific variables used in Blankespoor et al.

Before testing the hypothesis, we first examine the explanatory power of the consolidated and parent-only leverage ratios separately in Models 1 and 2, where CLev is a placeholder for CLev1 or CLev2 and PLev is a placeholder for PLev1 or PLev2:

$$
\begin{aligned}
& C D S P_{a d j}=\mathrm{a}_{0}+\mathrm{a}_{1} \text { CLev }+\mathrm{a}_{2} \text { Spot }+\mathrm{a}_{3} \text { StdRet }+\mathrm{a}_{4} \text { PastDue }+\mathrm{a}_{5} \text { NonAccr }+\varepsilon . \\
& C D S P_{a d j}=\mathrm{b}_{0}+b_{1} \text { PLev }+\mathrm{b}_{2} \text { Spot }+\mathrm{b}_{3} \text { StdRet }+\mathrm{b}_{4} \text { PastDue }+\mathrm{b}_{5} \text { NonAccr }+\varepsilon .
\end{aligned}
$$

To test our hypothesis, we control for the consolidated leverage ratio and focus on the parent-only leverage ratio. A positive coefficient would support the information loss argument; an insignificant coefficient would support the mechanism mitigation argument. Model 3 is the regression for our primary analysis:

$$
C D S P_{a d j}=\mathrm{c}_{0}+\mathrm{c}_{1} \text { CLev }+\mathrm{c}_{2} \text { PLev }+\mathrm{c}_{3} \text { Spot }+\mathrm{c}_{4} \text { StdRet }+\mathrm{c}_{5} \text { PastDue }+\mathrm{c}_{6} \text { NonAccr }+\varepsilon .
$$

The control variables Spot and StdRet are based on Callen et al. (2009). Spot is the mean value of daily 1-year treasury bill rates during fiscal quarter $t$. A higher rate decreases the market value of the sample firm's existing debt (implying that the firm borrowed money when the interest rate was lower), thereby decreasing the likelihood of bankruptcy and therefore the CDS premium. StdRet is the standard deviation of the sample firm's daily stock returns during fiscal quarter $t$ and captures the volatility of the firm's resources to repay its debt. We expect a positive coefficient. ${ }^{17}$

\footnotetext{
${ }^{17}$ Callen et al. (2009) include multiple CDS contracts from the same firm-quarter. We drop their variables that control for maturity and restructuring clauses because our CDS contracts are homogenous in these contract features. Callen et al. focus on earnings performance, such as return on assets (ROA). We add this variable in a supplementary analysis because our focus is on leverage and we want to avoid discussing in the primary analyses whether to use consolidated or parent-only total assets in calculating ROA.
} 
PastDue and NonAccr control for the quality of a bank's loans and are collected from the FR Y-9C report. PastDue is the amount of loans that are 30 days or more past due and still accruing interest, scaled by total assets. NonAccr is the amount of loans that are not in interest-accrual status (worse-performing loans than PastDue), scaled by total assets. We expect positive coefficients for PastDue and NonAccr.

\section{Primary Analyses}

\subsection{Sample collection}

We obtain CDS data covering 2001 to early 2018 from Markit, which records a composite daily premium for each CDS contract using quotes from a variety of market makers. We collect the premia of 5year CDS contracts for senior unsecured debt of U.S. firms, requiring MR (XR) clauses before (in or after) 2009. ${ }^{18}$ All banks end their fiscal years on December 31. Our sample selection begins with the fourth fiscal quarter of 2000 and ends with the fourth quarter of 2017.

We require bank-quarters to have Y-9LP reports and non-missing PERMCO in the Federal Reserve Bank of New York's file that enables matching of Y-9LP reports with Compustat. ${ }^{19}$ We require a bankquarter to have bonds outstanding so that we can focus on firms with public debt. These procedures give us 7,444 bank-quarters. After excluding 6,427 observations without CDS coverage and 85 without data for control variables, we have 932 bank-quarters from 30 unique banks. See Table 1 for the summary of sample collection and Appendix 2 for the bank list.

\subsection{Descriptive statistics}

Panel A of Table 2 reports descriptive statistics. Consistent with prior research, the raw $C D S$ premium is highly skewed, with a mean of 97.36 and a median of 69.12 basis points. The untabulated log-

\footnotetext{
${ }^{18}$ The deadline for FR Y-9LP is 45 days after the fiscal quarter end. The release date of an FR Y-9LP report is not publicly available and the vast majority of bank regulatory reports are filed near their due dates (Badertscher, Burks, and Easton 2018). Because for a bank-quarter we need the CDS premium quoted 45 days after the quarter end, we collect CDS with MR clauses for bank-quarters ending before 2009 and XR clauses for bank-quarters ending in or after 2009.

${ }^{19}$ The datafile is downloadable at the Federal Reserve Bank of New York website at: http://www.newyorkfed.org/research/banking_research/datasets.html.
} 
transformed variable, $C D S P$, has a mean (median) value of 4.18 (4.24). The mean value of $C D S P_{a d j}$ is 0.23 , meaning that, on average, our sample banks' CDS premia are higher than those of firms with the same credit rating.

On average, total debt reported in the parent-only balance sheet, PTotalDebt, is $\$ 36.33$ billion, whereas total debt reported in the consolidated balance sheet, CTotalDebt, is $\$ 131.32$ billion. Parent-only (consolidated) total assets are $\$ 98.86$ billion ( $\$ 497.05$ billion) on average. Figure 1 depicts the ratio of parent-only total debt to consolidated total debt in Panel A and the ratio of parent-only total assets to consolidated total assets in Panel B. The mean (median) ratio of PTotalDebt to CTotalDebt is $21.5 \%$ (19.1\%), suggesting that substantial outstanding debt is issued by subsidiaries (untabulated).

Panel A (Panel B) of Figure 2 depicts the leverage measures for the parent company (the consolidated reporting entity). We discuss the second leverage measurement first. When we scale total debt by total assets, the leverage ratio based on the parent-only balance sheet (PLev2, with a mean of 0.22$)$ and the leverage ratio based the consolidated balance sheet (CLev2, with a mean of 0.22$)$ are comparable in magnitude. However, the difference between these two leverage ratios, Delta2, has substantial variation, ranging from -0.42 to 0.28 with a median value of 0.01 (untabulated). As Figure 3 depicts, the distribution of Delta2 centers on zero, meaning that the parent-only leverage ratio is higher than the consolidated leverage ratio for about half of our sample firms. These firms tend to have a highly leveraged parent, but some subsidiaries have low outstanding debt. After consolidation, subsidiaries add little to consolidated total debt (the numerator of the leverage ratio), but greatly increase consolidated total assets (the denominator of the leverage ratio), lowering the consolidated leverage ratio. So, the actual credit risk of the parent is much higher than what is implied by the consolidated leverage ratio. The contrary applies to the other half of sample firms that have lower parent-only leverage than consolidated leverage.

When we scale total debt by the sum of total debt and equity, CLev1 and PLev1 have a mean value of 0.64 and 0.26 , respectively. CLev1 has a much higher mean than CLev2, even though the two ratios have the same numerator. This is because, on average, only $10 \%$ of a sample bank's consolidated total assets are funded by equity; $22 \%$ are funded by debt and the remaining $68 \%$ are funded by non-debt liabilities. Capital 
structure also explains the much higher CLev1 than PLev1: 63\% of parent-only total assets are funded by equity, $22 \%$ are funded by debt, and $15 \%$ are funded by non-debt liabilities.

Panel B of Table 2 reports pairwise Pearson and Spearman correlations. Both PLev1 and PLev2 are significantly positively correlated with $C D S P_{a d j}$, consistent with the idea that the parent-only balance sheet is useful for assessing the parent's credit risk. CLev1 and CLev2 are also significantly positively correlated with CDSP adj, but the magnitudes of correlations are about half of those for PLev1 and PLev2.

\subsection{Levels analysis}

Table 3 reports the regression results. We use the first set of leverage measurements in Columns 13, and the second set in Columns 4-6. Following Leone, Minutti-Meza, and Wasley (2019), we use robustregression estimations throughout our analyses to mitigate the effects of influential observations in both the dependent and independent variables. ${ }^{20}$

First, we examine the explanatory power of the consolidated leverage ratio. The coefficients on CLev1 and CLev2 are significantly positive in Model 1. Thus, the consolidated leverage ratio is associated with the pricing of credit risk. This result is expected because as a general-purpose financial reporting statement, the consolidated balance sheet is supposed to be the primary source of credit-risk information to debt holders. Second, we examine the explanatory power of the parent-only leverage ratio. The coefficients on PLev1 and PLev2 are significantly positive in Model 2, suggesting that the parent-only leverage ratio is also associated with the pricing of credit risk.

To compare the relative usefulness of the consolidated vs. parent-only leverage ratio, we perform the Vuong test to compare the explanatory power of non-nested Models 1 and 2 (Dechow 1994). The zstatistic is significant negative for the CLev2 and PLev2 comparison; the comparison between CLev1 and PLev1 models yields no significant difference. These results suggest that there is some evidence that the

\footnotetext{
${ }^{20}$ The robust regression estimation method iteratively reweights observations until the estimated coefficients converge. This method is superior to traditional methods (e.g., winsorization and truncation) that deal with outliers because it identifies influential observations in a multivariate distribution and downweighs them (Anderson 2008; Leone, Minutti-Meza, and Wasley 2019).
} 
parent-only leverage ratio is more useful for assessing the parent's credit risk than the consolidated leverage ratio.

We report the test of our hypothesis in the columns marked as Model 3, which includes both the consolidated and the parent-only leverage ratios. The coefficients on PLev1 and PLev2 are significantly positive, suggesting that the parent-only leverage ratio is useful for assessing credit risk beyond the consolidated leverage ratio. The economic effect is significant. For example, the coefficient on PLev2 is 0.527. If we increase PLev2 from the $25^{\text {th }}$ to $75^{\text {th }}$ percentile-from 0.11 to 0.28 - while holding all other independent variables constant, the CDS premium increases by $9.4 \%(\exp [0.527 * 0.17]=1.094)$. Our finding supports the information loss argument and does not support the mechanism mitigation argument.

\subsection{Changes analysis}

Following Callen et al. (2009) and Givoly et al. (2017), we estimate a changes regression. The changes research design can mitigate the concern about omitted correlated variables in the levels regression but may lack power if the explanatory or dependent variables do not vary much during the measurement period for changes. We calculate a change variable as the level variable measured for fiscal quarter $t$ minus that for fiscal quarter $t-1$. Models 4, 5, and 6 are the changes regressions of Models 1, 2, and 3, respectively:

$$
\begin{aligned}
& \Delta C D S P_{a d j}=\mathrm{d}_{0}+\mathrm{d}_{1} \Delta C L e v+\mathrm{d}_{2} \Delta \text { Spot }+\mathrm{d}_{3} \Delta \text { StdRet }+\mathrm{d}_{4} \Delta \text { PastDue }+\mathrm{d}_{5} \Delta \text { NonAccr }+\varepsilon . \\
& \Delta C D S P_{a d j}=\mathrm{e}_{0}+\mathrm{e}_{1} \Delta \text { PLev }+\mathrm{e}_{2} \Delta \text { Spot }+\mathrm{e}_{3} \Delta \text { StdRet }+\mathrm{e}_{4} \Delta \text { PastDue }+\mathrm{e}_{5} \Delta N o n A c c r+\varepsilon . \\
& \Delta C D S P_{a d j}=\mathrm{f}_{0}+\mathrm{f}_{1} \Delta C L e v+\mathrm{f}_{2} \Delta \text { PLev }+\mathrm{f}_{3} \Delta \text { Spot }+\mathrm{f}_{4} \Delta \text { StdRet }+\mathrm{f}_{5} \Delta \text { PastDue }+\mathrm{f}_{6} \Delta N o n A c c r+\varepsilon .
\end{aligned}
$$

Table 4 reports the estimation results. The number of observations decreases from 932 in Table 3 to 844 in Table 4 . The decrease of 88 bank-quarters include 48 (31) observations for which lagged leverage (lagged CDS premium) is unavailable and 9 observations that use MR for quarter $t-1$ but XR for quarter $t$ around the CDS Big Bang.

In Models 4 and 5, both the change in consolidated leverage, $\triangle C L e v$, and the change in parent-only leverage, $\triangle P L e v$, are separately positively associated with the CDS premium. More importantly, when we include both the consolidated and parent-only leverage change variables in Model 6, the coefficients on 
$\triangle P L e v 1$ and $\triangle P L e v 2$ remain significantly positive, but the coefficients on $\triangle C L e v 1$ and $\triangle C L e v 2$ are no longer statistically significant at the conventional level. These results suggest that the change in parent-only leverage subsumes the change in consolidated leverage and provide additional explanatory power for the pricing of the parent's credit risk.

\section{Supplementary Analyses}

\subsection{Controlling for accounting performance}

Callen et al. (2009) find that earnings convey information about credit risk. They regress the CDS premium on ROA, where ROA is measured as consolidated net income before extraordinary items divided by consolidated total assets. We refer to this variable as $C R O A$. We then calculate the parent-only net income divided by parent-only total assets and refer to the new variable as PROA. When Callen et al. (2009) add ROA to their baseline model, they also add firm size to proxy for a firm's overall information environment. We follow their practice and add firm size when controlling for ROA. Size is the natural logarithm of market capitalization of common equity measured at the end of quarter $t$. Panel A of Table 5 presents the estimation results. Consistent with Callen et al. (2009), both earnings performance variables are significantly negatively associated with the CDS premium. Our primary finding is robust.

\subsection{Controlling for liquidity risk}

The CDS premium may reflect the liquidity risk of a CDS contract in addition to the credit risk of the reference entity (Kapadia and Pu 2012). Following Arora et al. (2014), we use Size and Depth to proxy for liquidity risk. Depth is the mean daily number of market makers who provide quotes to Markit during fiscal quarter $t$ regarding the CDS contract. We lose 18 observations for missing Depth. On average, five market makers provide quotes for a 5-year CDS contract on senior unsecured debt. Panel B of Table 5 presents the estimations after adding these two variables. Depth has a negative but insignificant coefficient, whereas Size is significantly negatively associated with the CDS premium, consistent with our expectation. More importantly, PLev1 and PLev2 remain significantly positively associated with the CDS premium. 


\subsection{Expanding the sample and using bond spreads}

Our primary analyses use a small sample size because many banks are not referenced firms in CDS contracts. The referenced firms are typically large and well-performing borrowers with low default risk (Shan, Tang, and Winton 2019; Demerjian 2019). In this subsection, we expand our sample by forgoing the requirement of CDS contracts and instead selecting banks that have bond issuances during our sample period. We examine the association of the parent-only leverage ratio with the pricing of credit risk at bond issuance—-bond spreads.

We obtain data about bond issuance from the Securities Data Corporation database and exclude convertible bonds, bonds with callable features, and bonds without credit ratings. For each bond, we identify the most recently released FR Y-9LP report before the bond issuance date and the corresponding consolidated financial statements. ${ }^{21}$ Our sample consists of 3,569 bond issuances by 73 banks. This sample is comparable to prior studies that examine bonds issued by banks. For example, Blankespoor et al. (2013) examine 1,861 bonds issued by 46 banks during 1998-2010. The sample of our bond analyses is significantly larger and much more representative of public banks than our CDS sample.

Parallel to Models 1-3, we first examine the explanatory power of the consolidated and parent-only leverage ratios separately in Models 7 and 8, and then include both leverage ratios in Model 9:

$$
\begin{aligned}
\text { BondSpread }= & \mathrm{g}_{0}+\mathrm{g}_{1} \text { CLev }+\mathrm{g}_{2} \text { Size }+\mathrm{g}_{3} \text { MTB }+\mathrm{g}_{4} \text { InvGrade }+\mathrm{g}_{5} \log (\text { Amount }) \\
& +\mathrm{g}_{6} \text { Log }(\text { Maturity })+\mathrm{g}_{7} \text { Secured }+\varepsilon \\
\text { BondSpread }= & \mathrm{j}_{0}+\mathrm{j}_{1} \text { PLev }+\mathrm{j}_{2} \text { Size }+\mathrm{j}_{3} \text { MTB }+\mathrm{j}_{4} \text { InvGrade }+\mathrm{j}_{5} \log (\text { Amount }) \\
& +\mathrm{j}_{6} \log (\text { Maturity })+\mathrm{j}_{7} \text { Secured }+\varepsilon \\
\text { BondSpread }= & \mathrm{k}_{0}+\mathrm{k}_{1} \text { CLev }+\mathrm{k}_{2} \text { PLev }+\mathrm{k}_{3} \text { Size }+\mathrm{k}_{4} \text { MTB }+\mathrm{k}_{5} \text { InvGrade } \\
& \left.+\mathrm{k}_{6} \text { Log }(\text { Amount })+\mathrm{k}_{7} \text { Log (Maturity }\right)+\mathrm{k}_{8} \text { Secured }+\varepsilon
\end{aligned}
$$

The dependent variable, BondSpread, is the interest spread in basis point at bond issuance over the interest rate on the treasury bill of same maturity on the day of bond issuance. We follow Bharath et al. (2008) and Blankespoor et al. (2013) in selecting the control variables. Size controls for firm size because

\footnotetext{
${ }^{21}$ For example, the due dates of FR Y-9LP reports for 2016Q1 and 2016Q2 are May 16, 2016 and August 15, 2016, respectively. If a bank issued three different bonds on May 20, 2016, July 30, 2016, and August 19, 2016, we would match the first two bonds with the 2016Q1 Y-9LP report and the last one with the 2016Q2 Y-9LP report.
} 
larger banks are more diversified and therefore have lower credit risk. MTB controls for expected future growth of the borrower. InvGrade is an indicator for investment grade and controls for the credit risk information provided publicly by rating agencies. ${ }^{22} \log ($ Amount), Log (Maturity), and Secured control for bond features. See variable definitions in Appendix 1.

Panel A of Table 6 reports the descriptive statistics. The mean (median) bond spreads is 118.61 (95.00) basis points and the maturity is 168.35 (121.77) months. These bond characteristics are similar to the statistics in Bharath et al. (2008). Panel B of Table 6 reports pairwise Pearson and Spearman correlations. BondSpread is positively correlated with the parent-only leverage ratios, PLev1 and PLev2, the consolidated leverage ratios, CLev1 and CLev2, and maturity and is negatively correlated with MTB and InvGrade.

Panel C of Table 6 reports the regression results. In Columns 1 and 4, the consolidated leverage ratios, CLev1 and CLev2, are positively associated with bond spreads, suggesting that the consolidated leverage provides information about credit risk to bond holders. In Columns 2 and 5, the parent-only leverage ratios, $P$ Lev1 and $P$ Lev2, have significantly positive coefficients, suggesting that the parent-only leverage also provides relevant credit risk information to bond holders. The Vuong test result $(z$-stat $=-2.56$, p-value $=0.01)$ indicates that $P L e v 1$ has significantly greater explanatory power than CLev1. The Vuong test between Columns 4 and 5 yields no significant difference. These results provide some evidence that the parent-only leverage is more useful for assessing the parent's credit risk than the consolidated leverage.

More importantly, in Column 3 (Column 6) we find that PLev1 (PLev2) has significant incremental explanatory power beyond CLev1 (CLev2), suggesting that the parent-only leverage is incrementally useful to bond holders in assessing credit risk beyond the consolidated leverage. Our bond analyses corroborate

\footnotetext{
${ }^{22}$ Our results are similar if we control for the credit rating variable instead. We control for the investment grade indicator to be consistent with Bharath et al. (2008). We do not adjust for credit rating in the dependent variable as we do in the CDS analyses because (1) bond features vary, affecting bond spreads and (2) bond issuances are not frequent events, making it difficult for us to form a benchmark portfolio that includes the bond issuances of other firms with the same credit rating on the same date as the sample firm's bond issuance.
} 
our primary findings drawn from the smaller CDS sample. The consistency mitigates the concern that our CDS sample is too small for the findings to be generalized to all banks.

\section{Conclusion}

We use bank regulatory data and provide evidence that the parent-only balance sheet is incrementally useful for assessing the parent's credit risk beyond the general-purpose consolidated balance sheet. Our findings may or may not be generalizable to non-financial firms. On the one hand, banks' business models are unique. A bank holding company often holds many subsidiaries, which carry out actual operations. What we learn from the banking industry may not apply to other industries. On the other hand, given the widely held "too big to fail" perception and actual rescues of troubled banks by the government during the financial crisis, banks' debt holders might have weaker incentives to assess and monitor credit risk than non-banks. Evidence of the usefulness of parent-only balance sheets in weak-incentive situations may imply their increased usefulness in situations where debt holders have strong incentives to discipline companies. Our findings at least raise the question of whether debt holders' information needs are better served if consolidated financial statements are supplemented with parent-only financial statements. 


\section{References}

Anderson, R. 2008. Modern Methods for Robust Regression. Thousand Oaks, CA: Sage Publications.

Armstrong, C. S., W. R. Guay, and J. P. Weber. 2010. The role of information and financial reporting in corporate governance and debt contracting. Journal of Accounting and Economics 50: 179-234.

Arora, N, S. Richardson, and I. Tuna. 2014. Asset reliability and security prices: Evidence from credit markets. Review of Accounting Studies 19: 363-395.

Badertscher, B. A., J. J. Burks, and P. D. Easton. 2018. The market reaction to bank regulatory reports. Review of Accounting Studies 23: 686-731.

Bar-Isaac, H. and J. Shapiro. 2011. Credit ratings accuracy and analyst incentives. American Economic Review 101 (3): 120-124.

Bharath S. T., J. Sunder, and S.V. Sunder. 2018. Accounting quality and debt contracting. The Accounting Review 83: 1-28.

Beaver, W. H., S. Cascino, M. Correia, and M. F. McNichols. 2018. Group affiliation and default prediction. Management Science. Forthcoming.

Belenzon, S., H. Lee, and A. Pataconi. 2018. Toward a legal theory of the firm: The effects of enterprise liability on asset partitioning, decentralization and corporate group growth. NBER Working Paper 24720.

Berger, P. and R. Hann. 2003. The impact of SFAS No. 131 on information and monitoring. Journal of Accounting Research 41 (2): 163-223.

Blankespoor, E., T. J. Linsmeier, K. R. Petroni, and C. Shakespeare. 2013. Fair value accounting for financial instruments: Does it improve the association between bank leverage and credit risk? The Accounting Review 88 (4): 1143-1177.

Callen, J., J. Livnat, and D. Segal. 2009. The impact of earnings on the pricing of credit default swaps. The Accounting Review 84 (5): 1363-1394.

Carrizosa, R. and S. G. Ryan. 2017. Borrower private information covenants and loan contract monitoring. Journal of Accounting and Economics 64: 313-339.

Coquillette, W. 1980. Guaranty of and security for the debt of a parent corporation by a subsidiary corporation. Case Western Reserve Law Review 30 (3): 433-460.

Das, S., M. Kalimipalli, and S. Nayak. 2014. Did CDS trading improve the market force for corporate bonds? Journal of Financial Economics 111: 495-525.

Dechow, P. 1994. Accounting earnings and cash flows as measures of firm performance: The role of accounting accruals. Journal of Accounting and Economics 18: 3-42.

Demerjian P. 2019. How do lenders monitor? A discussion of Shan, Tang, and Winton (2019). Journal of Accounting and Economics. Forthcoming.

DiMatteo, L. and R. Sacasas. 1995. Credit and value "comfort" instruments: Crossing the line from assurance to legally significant reliance and toward a theory of enforceability. Baylor University Law Review 47: 357-423.

Flannery, M. J., and S. M. Sorescu. 1996. Evidence of bank market discipline in subordinated debenture yields: 1983-1991. Journal of Finance 51 (4): 1347-1377.

Francis, J. 1986. Debt reporting by parent companies: parent-only versus consolidated statements. Journal of Business Finance and Accounting 13 (3): 393-403.

Givoly, D., C. Hayn, and S. Katz. 2017. The changing relevance of accounting information to debt holders over time. Review of Accounting Studies 22: 64-108.

Gomes, A. and G. Phillips. 2012. Why do public firms issue private and public securities? Journal of Financial Intermediation 21: 619-658.

Graham, J., S. Li, and J. Qiu. 2008. Corporate misreporting and bank loan contracting. Journal of Financial Economics 89: 44-61.

Herrmann D., T. Inoue, and W. Thomas. 2001. The relation between incremental subsidiary earnings and future stock returns in Japan. Journal of Business Finance and Accounting 28 (9\&10): 1115-1139. 
Jiang, J., M. H. Stanford, and Y. Xie. 2012. Does it matter who pays for bond ratings? Historical evidence. Journal of Financial Economics 105: 607-621.

Kapadia, N. and X. Pu. 2012. Limited arbitrage between equity and credit markets. Journal of Financial Economics 105: 542-564.

Kedia, S., S. Rajgopal, and X. Zhou. 2014. Did going public impair Moody's credit ratings? Journal of Financial Economics 114: 293-315.

Krishnan, C. N. V., P. H. Ritchken, and J. B. Thomson. 2005. Monitoring and controlling bank risk: Does risky debt help? Journal of Finance 60 (1): 343-378.

Lee, J., A. Naranjo, and G. Velioglu. 2018. When do CDS spreads lead? Rating events, private entities, and firm-specific information flows. Journal of Financial Economics 130: 556-578.

Leone, A. J., M. Minutti-Meza, and C. E. Wasley. 2019. Influential observations and inference in accounting research. The Accounting Review. Forthcoming.

Lipe, R. C. 1986. The information contained in the components of earnings. Journal of Accounting Research 24: 37-64.

Minnis, M. and N. Shroff. 2017. Why regulate private firm disclosure and auditing? Accounting and Business Research 47 (5): 473-502.

Morningstar. 2015. Methodology for rating parents, subsidiaries, and issues.

Oehmke, M. and A. Zawadowski. 2017. The anatomy of the CDS market. Review of Financial Studies 30 (1): 80-119.

Ohlson, J. and S. H. Penman. 1992. Disaggregated accounting data as explanatory variables for returns. Journal of Accounting, Auditing, and Finance 7: 553-573.

Pacter, P. 1993. Reporting Disaggregated Data. FASB Research Report.

Rajan, R., and L. Zingales. 1995. What do we know about capital structure? Some evidence from international data. Journal of Finance 50 (5): 1421-1460.

Shan, C., D. Tang, and A. Winton. 2019. Do banks still monitor when there is a market for credit protection? Journal of Accounting and Economics. Forthcoming.

Securities Exchange Commission (SEC). 2015. Capital raising in the U.S.: An analysis of the market for unregistered securities offerings, 2009-2014. White paper. October.

Walker, R. G. 1976. An evaluation of the information conveyed by consolidated statements. Abacus 12(2): 77-115.

Weiss, S. 1985. A balance-sheet buster from the FASB. Business Week (June 10, 1985).

Zhang, B. Y., H. Zhou, and H. Zhu. 2009. Explaining credit default swap spreads with the equity volatility and jump risks of individual firms. Review of Financial Studies 12 (12): 5099-5131. 


\title{
Appendix 1 \\ Variable Definitions
}

\begin{abstract}
Balance-sheet variables (firm-quarter observations)
PTotalDebt = parent-only total debt in billions of dollars at the end of fiscal quarter $t$, obtained from FR Y-9LP report Schedule PC "Parent Company Only Balance Sheet," measured as the sum of borrowings with remaining maturity of one year or less (liability Item 13) and borrowings with remaining maturity of more than one year (liability Item 14);

CTotalDebt $=$ consolidated total debt in billions of dollars at the end of fiscal quarter $t$, measured as the sum of debt listed in current liabilities (Compustat $D L C Q$ ) and long-term debt (Compustat DLTTQ);

PTotalAssets = parent-only total assets in billions of dollars at the end of fiscal quarter $t$, obtained from FR Y-9LP report Schedule PC;

CTotalAssets $\quad=$ consolidated total assets in billions of dollars at the end of fiscal quarter $t$ (Compustat $A T Q)$;

PLev1 = financial leverage at the end of fiscal quarter $t$ based on the parent-only balance sheet, measured as the ratio of PTotalDebt to capital, where capital is defined as the sum of PTotalDebt and total common shareholders' equity reported in FR Y-9LP;

PLev2 = financial leverage at the end of fiscal quarter $t$ based on the parent-only balance sheet, measured as the ratio of PTotalDebt to total assets reported in FR Y-9LP;

CLev1 = financial leverage at the end of fiscal quarter $t$ based on the consolidated balance sheet, measured as the ratio of CTotalDebt to capital, where capital is defined as the sum of CTotalDet and total common shareholders' equity in Compustat;

CLev2 = financial leverage at the end of fiscal quarter $t$ based on the consolidated balance sheet, measured as the ratio of CTotalDebt to total assets in Compustat.
\end{abstract}

\begin{tabular}{ll}
\hline CDS pricing of credit risk (firm-quarter observations) \\
\hline$C D S P_{\text {(raw) }}$ & $=$ the premium (in basis points) of 5-year CDS, for which the sample firm's senior \\
& unsecured debt is the deliverable obligation, on the first trading day after the Y-9LP \\
& filing due date (i.e., the $45^{\text {th }}$ calendar day following the end of fiscal quarter) for fiscal \\
& quarter $t$. We obtain the data from the Markit database; \\
& $=$ the natural logarithm of $C D S P_{(\text {raw }}$; \\
& $=C D S P$ minus the natural logarithm of the median premium (in basis points) of 5- \\
& year CDS contracts, for which the deliverable obligation is the senior unsecure debt of \\
& a U.S. firm in the same S\&P credit rating category as the sample firm, covered in the \\
& Markit database on the same day when $C D S P$ is measured.
\end{tabular}

Control variables for CDS pricing tests (firm-quarter observations)

Spot $\quad=$ the mean value of daily 1-year treasury bill rates during fiscal quarter $t$;

StdRet

$=$ the standard deviation of the parent firm's daily stock returns during fiscal quarter $t$;

PastDue

$=$ the loans that are 30 days or more past due and still accruing interest at the end of fiscal quarter $t$ according to the FR Y-9C report, scaled by total assets on the same balance sheet;

NonAccr $\quad=$ the loans not in interest-accrual status (the loans are 90 days or more overdue, the payment in full of principal or interest is not expected, or the loans are maintained on a cash basis because of deterioration in the borrower's financial condition) at the end of fiscal quarter $t$ according to the FR Y-9C report, scaled by total assets on the same balance sheet;

CROA = consolidated net income before extraordinary items divided by consolidated total assets at the end of fiscal quarter $\mathrm{t}$; 
PROA = parent-only net income divided by parent-only total assets at the end of fiscal quarter $\mathrm{t}$;

Size $\quad=$ the natural logarithm of market capitalization of equity in millions of dollars at the end of fiscal quarter $t$;

Depth = the mean daily number of market makers that provide CDS quotes, collected by the Markit database, during fiscal quarter $t$. Here, the CDS is a 5-year contract for which the sample firm's senior unsecured debt is the deliverable obligation.

\begin{tabular}{|c|c|}
\hline \multicolumn{2}{|c|}{ Variables used in supplementary bond pricing tests (bond issuance observations) } \\
\hline BondSpread & $\begin{array}{l}=\text { the interest spread in basis point at bond issuance over the interest rate on the treasury } \\
\text { bill of same maturity on the day of bond issuance. We obtain bond issuance and bond } \\
\text { spread data from the Securities Data Corporation database; }\end{array}$ \\
\hline$M T B$ & $\begin{array}{l}=\text { the ratio of market value of total assets over book value of total assets at the end of } \\
\text { the most recent fiscal quarter before bond issuance, where the numerator is total assets } \\
\text { minus book value of equity plus market capitalization of equity; }\end{array}$ \\
\hline InvGrade & $\begin{array}{l}=1 \text { if the bond credit rating is investment grade (i.e., } \mathrm{S} \& \mathrm{P} \text { rating is BBB- or higher, or } \\
\text { Moody rating is Baa } 3 \text { or higher) and } 0 \text { otherwise; }\end{array}$ \\
\hline $\log ($ Amount $)$ & illions of dollars; \\
\hline Log(Maturity) & $=$ the natural logarithm of the maturity (in months) of the bond; \\
\hline Secured & $=1$ if the bond is secured with collateral and 1 otherwise. \\
\hline & ev1, CLev2, and Size are now measured at the end of the most recent fiscal qua \\
\hline
\end{tabular}




\section{Appendix 2 \\ List of Sample Banks}

\begin{tabular}{ll}
\hline 1 & American Express Company \\
2 & American International Group, Inc. \\
3 & Bank of America Corporation \\
4 & Bank of New York Company, Inc. ${ }^{~}$ \\
5 & BB\&T Corporation \\
6 & Capital One Financial Corporation \\
7 & Charles Schwab Corporation \\
8 & Citigroup Inc. \\
9 & Discover Financial Services \\
10 & E*Trade Financial Corporation \\
11 & Fifth Third Bancorp \\
12 & FleetBoston Financial Corporation \\
13 & Franklin Resources, Inc. \\
14 & Goldman Sachs Group, Inc. \\
15 & J.P. Morgan Chase \& Co. \\
16 & KeyCorp \\
17 & MBNA Corporation \\
18 & MetLife, Inc. \\
19 & Morgan Stanley \\
20 & National City Corporation \\
21 & Northern Trust Corporation \\
22 & PNC Financial Services Group, Inc. \\
23 & Popular, Inc. \\
24 & Principal Financial Group, Inc. \\
25 & Regions Financial Corporation \\
26 & SouthTrust Corporation \\
27 & State Street Corporation \\
28 & SunTrust Banks, Inc. \\
30 & U.S. Bancorp \\
\hline
\end{tabular}

\#: Bank of New York merged with Mellon Financial Corp on July 1, 2007.

': SouthTrust merged with Wachovia Corp on June 21, 2004. 
Figure 1

Parent-only Balance Sheet vs. Consolidated Balance Sheet

Panel A: The ratio of parent-only total debt to consolidated total debt

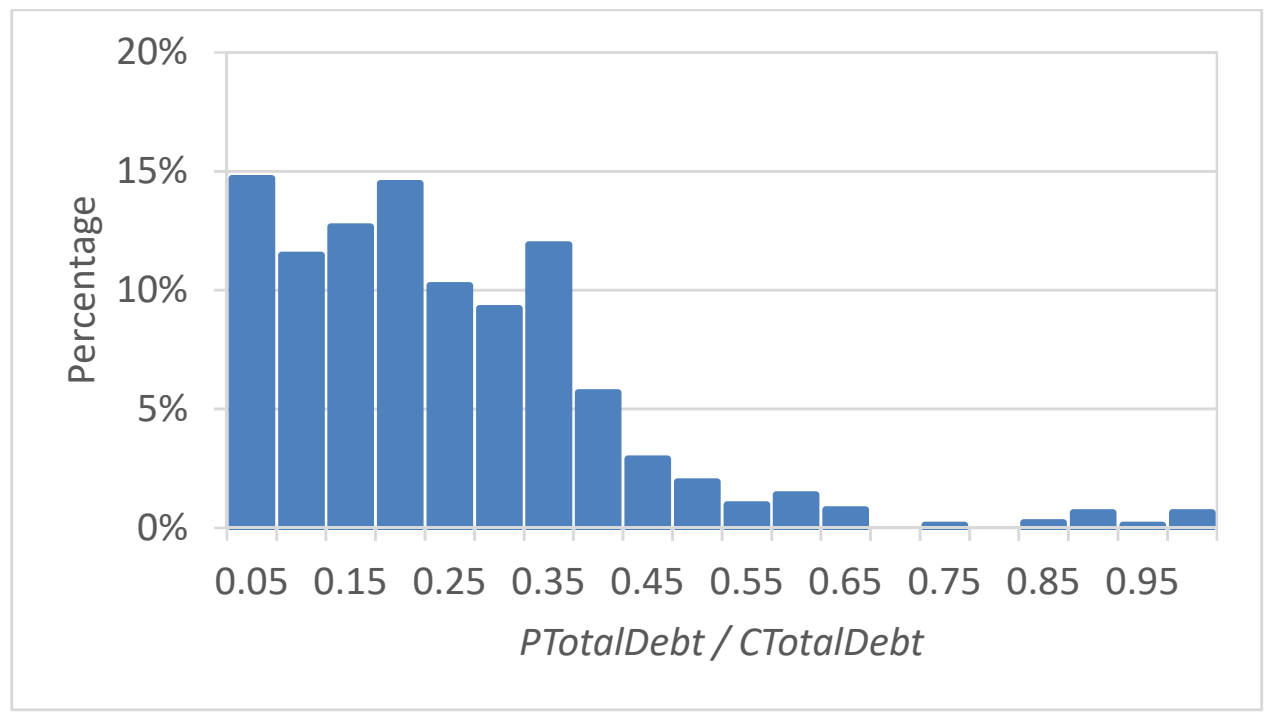

Panel B: The ratio of parent-only total assets to consolidated total assets

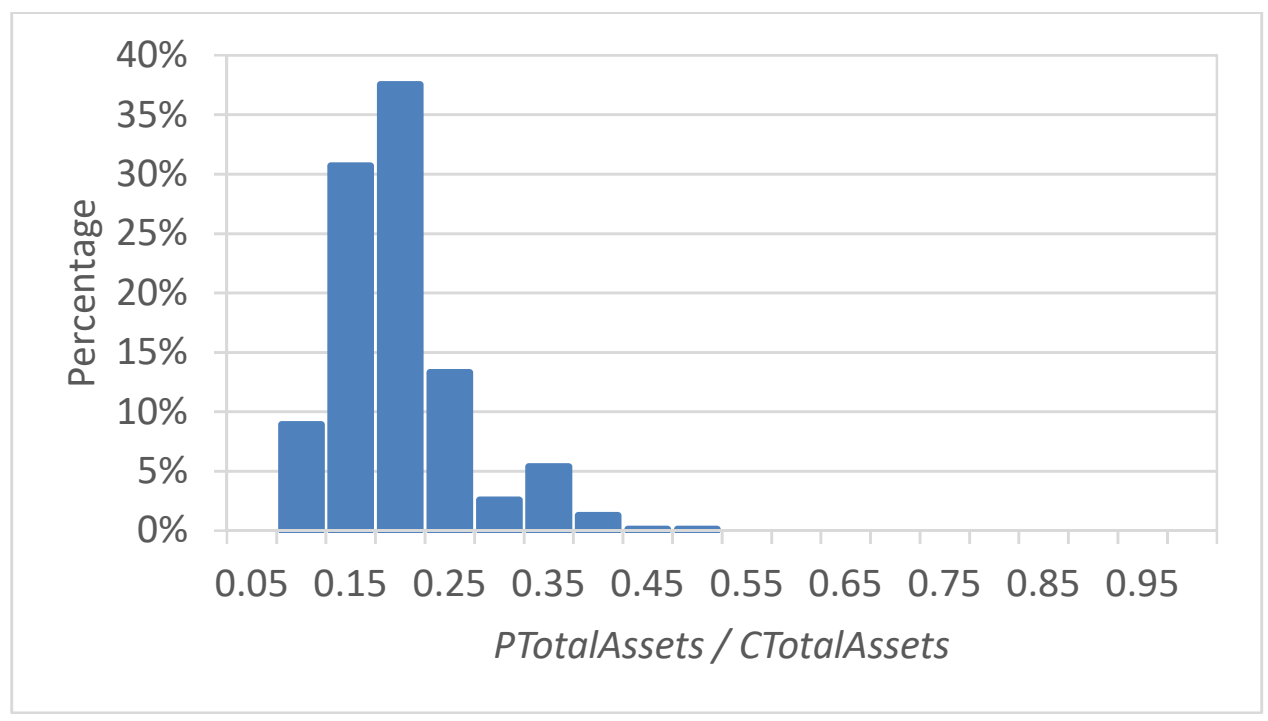

Note: In Panel A, we plot the distribution of PTotalDebt/CTotalDebt, the ratio of parent-only total debt to consolidated total debt. The width of each bar is 0.05 . Parent-only total debt, PTotalDebt, is measured as the sum of borrowings with a remaining maturity of one year or less (liability Item 13) and borrowings with a remaining maturity of more than one year (liability Item 14), obtained from Schedule PC of the FR Y9LP report. Consolidated total debt, CTotalDebt, is measured as the sum of debt listed in current liabilities (Compustat DLCQ) and long-term debt (Compustat DLTTQ). In Panel B, we plot the distribution of PTotalAssets/CTotalAssets, the ratio of parent-only total assets to consolidated total assets. The width of each bar is 0.05 . 
Figure 2

Parent-only Leverage vs. Consolidated Leverage

Panel A: Parent-only leverage

The first leverage measurement (PLev1)

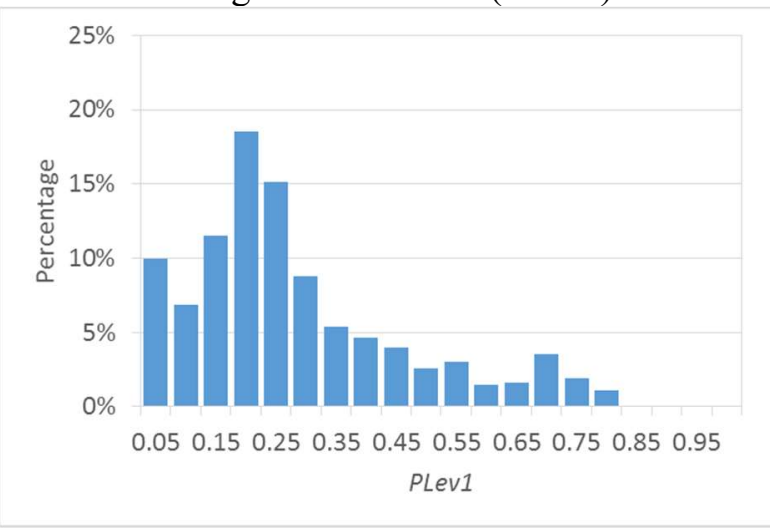

Panel B: Consolidated leverage

The first leverage measurement (CLevl)

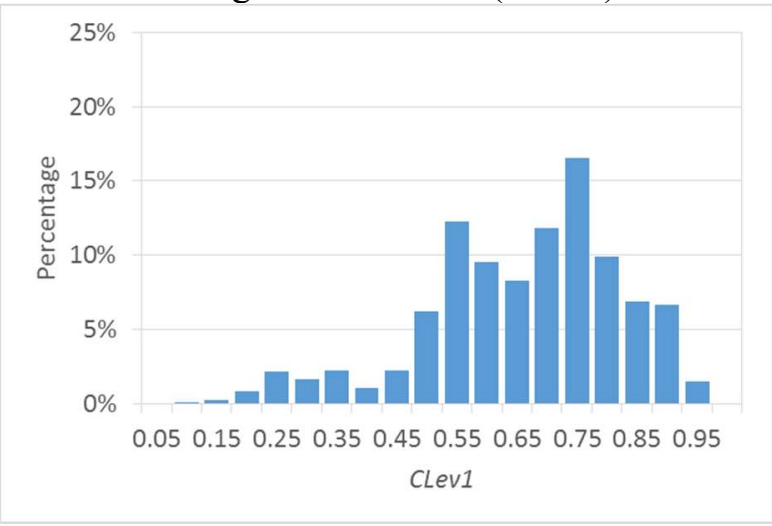

The second leverage measurement (PLev2)

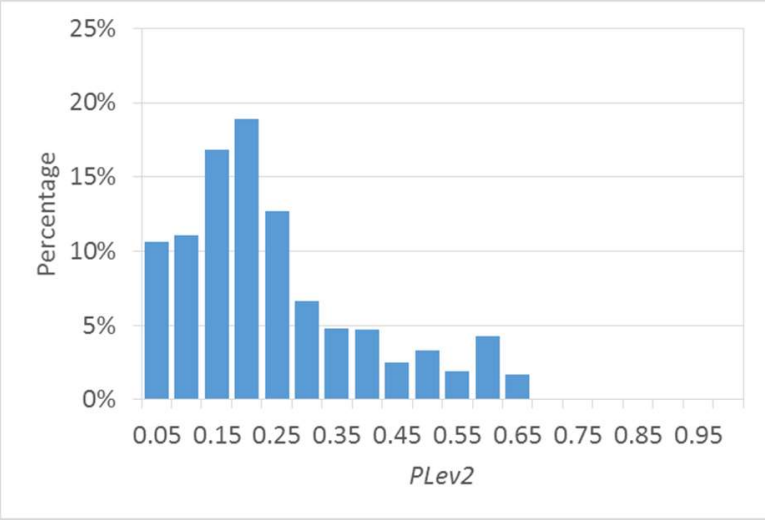

The second leverage measurement (CLev2)

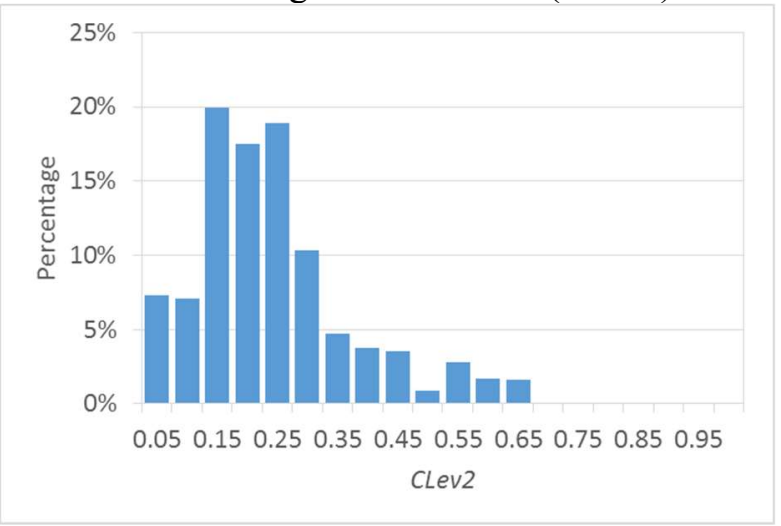

Note: In Panel A (B), we plot the distribution of the two leverage measures based on the parent-only (consolidated) balance sheet. See the definitions of PLev1, PLev2, CLev1, and CLev2 in Appendix 1. PLev1 is the financial leverage at the end of fiscal quarter $t$ based on the parent-only balance sheet, measured as the ratio of PTotalDebt to capital, where capital is defined as the sum of PTotalDebt and total common shareholders' equity. PLev2 is the financial leverage at the end of fiscal quarter $t$ based on the parent-only balance sheet, measured as the ratio of PTotalDebt to total assets. Here, PTotalDebt is the parent-only total debt, measured as the sum of borrowings with a remaining maturity of one year or less (liability Item 13) and borrowings with a remaining maturity of more than one year (liability Item 14), obtained from Schedule PC of the FR Y-9LP report. CLev1 is the financial leverage at the end of fiscal quarter $t$ based on the consolidated balance sheet, measured as the ratio of CTotalDebt to capital, where capital is defined as the sum of CTotalDet and total common shareholders' equity. CLev2 is the financial leverage at the end of fiscal quarter $t$ based on the consolidated balance sheet, measured as the ratio of CTotalDebt to total assets. Here, CTotalDebt is the consolidated total debt, measured as the sum of debt listed in current liabilities (Compustat DLCQ) and long-term debt (Compustat DLTTQ). 
Figure 3

Difference between Parent-only Leverage and Consolidated Leverage

Based on the first leverage measurement (Delta1)

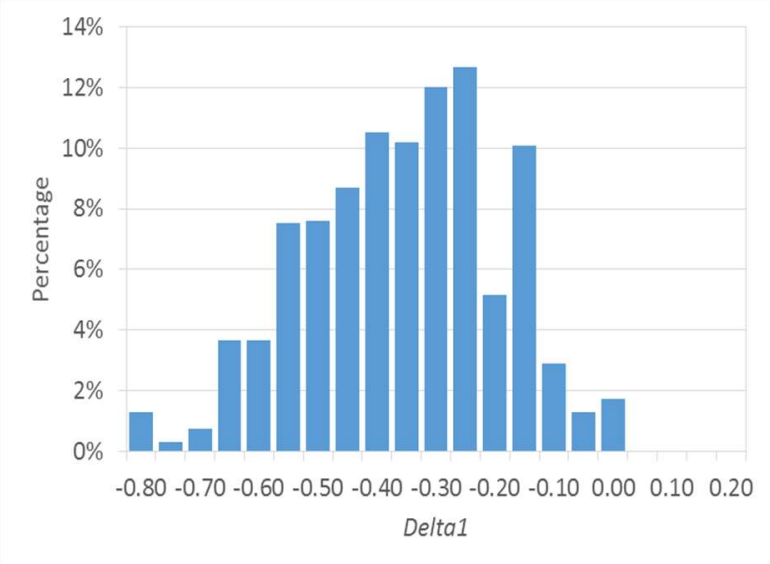

Based on the second leverage measurement (Delta2)

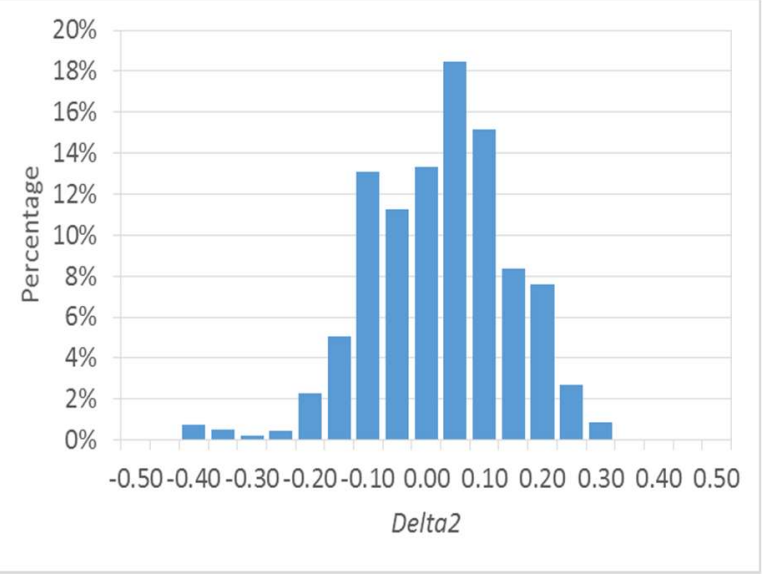

Note: We plot the distributions of Delta 1 and Delta 2. Delta1 is PLev1 minus CLev1. Delta2 is PLev2 minus CLev2. PLev1 is the financial leverage at the end of fiscal quarter $t$ based on the parent-only balance sheet, measured as the ratio of PTotalDebt to capital, where capital is defined as the sum of PTotalDebt and total common shareholders' equity. CLevl is the financial leverage at the end of fiscal quarter $t$ based on the consolidated balance sheet, measured as the ratio of CTotalDebt to capital, where capital is defined as the sum of CTotalDet and total common shareholders' equity. PLev2 is the financial leverage at the end of fiscal quarter $t$ based on the parent-only balance sheet, measured as the ratio of PTotalDebt to total assets. CLev2 is the financial leverage at the end of fiscal quarter $t$ based on the consolidated balance sheet, measured as the ratio of CTotalDebt to total assets. Here, PTotalDebt is the parent-only total debt, measured as the sum of borrowings with a remaining maturity of one year or less (liability Item 13) and borrowings with a remaining maturity of more than one year (liability Item 14), obtained from Schedule PC of the FR Y-9LP report. CTotalDebt is the consolidated total debt, measured as the sum of debt listed in current liabilities (Compustat $D L C Q$ ) and long-term debt (Compustat DLTTQ). 
Table 1

Sample Selection

\begin{tabular}{lcc}
\hline & Attrition & $\begin{array}{c}\text { Remaining } \\
\text { Observations }\end{array}$ \\
$\begin{array}{l}\text { Bank-quarters with FR Y-9LP filings during 2000Q4 - 2017Q4, } \\
\text { PERMCO identifier in Compustat, and bonds outstanding }\end{array}$ & 7,444 \\
Exclude bank-quarters without CDS coverage & $(6,427)$ & 1,017 \\
Exclude bank-quarters without data for control variables & $(85)$ & 932 \\
Bank-quarters for CDS pricing analyses & & 932 \\
\hline
\end{tabular}

Note: The table summarizes our sample selection process. Our CDS data is obtained from Markit. We use 5-year CDS contracts for senior unsecured debt with the sample firm (the parent) as the reference entity. Before the CDS Big Bang on April 8, 2009, CDS contracts with modified restructuring (MR) clauses were most popularly traded in the U.S. Since the Big Bang, CDS contracts with no restructuring (XR) clauses are most popularly traded in the U.S. For bank-quarters ending before 2009, we collect CDS with MR clauses; for bank-quarters ending in or after 2009, we collect CDS with XR clauses. For a bank-quarter, we use the CDS premium on the first trading day after the due date of the FR Y-9LP report, which is 45 days after the fiscal quarter end. The average market capitalization of our sample banks at the end of 2017 is $\$ 103$ billion, accounting for $61 \%$ of the total market capitalization of all public banks (including small banks that file FR Y-9SP and banks without outstanding bonds). 
Table 2

Descriptive Statistics

Panel A: Summary statistics

\begin{tabular}{lcccccc}
\hline & $\mathrm{N}$ & Mean & Std. dev. & P25 & Median & P75 \\
CDSP & 932 & 97.36 & 98.04 & 34.90 & 69.12 & 120.03 \\
CDSP adj $_{\text {PTotalDebt (in billions) }}$ & 932 & 0.23 & 0.54 & -0.13 & 0.15 & 0.51 \\
CTotalDebt (in billions) & 932 & 36.33 & 60.34 & 1.83 & 5.31 & 31.04 \\
PTotalAssets (in billions) & 932 & 131.32 & 196.31 & 17.72 & 34.58 & 103.92 \\
CTotalAssets (in billions) & 932 & 98.86 & 133.35 & 16.72 & 31.17 & 104.59 \\
CLev1 & 932 & 497.05 & 622.11 & 110.02 & 196.72 & 618.59 \\
CLev2 & 932 & 0.64 & 0.16 & 0.53 & 0.67 & 0.75 \\
PLev1 & 932 & 0.22 & 0.13 & 0.13 & 0.20 & 0.26 \\
PLev2 & 932 & 0.26 & 0.18 & 0.14 & 0.21 & 0.34 \\
Spot & 932 & 0.22 & 0.15 & 0.11 & 0.18 & 0.28 \\
StdRet & 932 & 1.52 & 1.65 & 0.20 & 0.58 & 2.32 \\
PastDue & 932 & 0.02 & 0.02 & 0.01 & 0.01 & 0.02 \\
NonAccr & 932 & $0.47 \%$ & $0.63 \%$ & $0.08 \%$ & $0.25 \%$ & $0.63 \%$ \\
\hline
\end{tabular}

Panel B: Pairwise correlations

\begin{tabular}{lccccccccc}
\hline & CDSP $P_{\text {adj }}$ & CLev1 & CLev2 & PLev1 & PLev2 & Spot & StdRet & PastDue & NonAccr \\
CDSP $P_{\text {adj }}$ & & $\mathbf{0 . 1 2}$ & 0.05 & $\mathbf{0 . 2 3}$ & $\mathbf{0 . 2 4}$ & $\mathbf{- 0 . 2 8}$ & $\mathbf{0 . 3 1}$ & 0.02 & 0.06 \\
CLev1 & $\mathbf{0 . 1 1}$ & & $\mathbf{0 . 9 5}$ & $\mathbf{0 . 5 2}$ & $\mathbf{0 . 4 6}$ & $\mathbf{0 . 1 5}$ & 0.03 & $\mathbf{- 0 . 0 9}$ & $\mathbf{0 . 1 3}$ \\
CLev2 & $\mathbf{0 . 1 2}$ & $\mathbf{0 . 8 6}$ & & $\mathbf{0 . 5 1}$ & $\mathbf{0 . 4 7}$ & $\mathbf{0 . 1 2}$ & 0.00 & -0.04 & 0.07 \\
PLev1 & $\mathbf{0 . 2 5}$ & $\mathbf{0 . 5 6}$ & $\mathbf{0 . 6 9}$ & & $\mathbf{0 . 9 8}$ & $\mathbf{- 0 . 1 9}$ & 0.06 & $\mathbf{- 0 . 1 0}$ & -0.06 \\
PLev2 & $\mathbf{0 . 2 5}$ & $\mathbf{0 . 5 2}$ & $\mathbf{0 . 6 6}$ & $\mathbf{0 . 9 9}$ & & $\mathbf{- 0 . 2 4}$ & 0.05 & -0.08 & -0.07 \\
Spot & $\mathbf{- 0 . 2 5}$ & 0.08 & -0.03 & $\mathbf{- 0 . 2 0}$ & $\mathbf{- 0 . 2 3}$ & & $\mathbf{- 0 . 1 3}$ & $\mathbf{- 0 . 2 7}$ & $\mathbf{- 0 . 2 6}$ \\
StdRet & $\mathbf{0 . 3 9}$ & $\mathbf{0 . 1 2}$ & 0.06 & 0.08 & 0.06 & $\mathbf{- 0 . 1 5}$ & & 0.07 & $\mathbf{0 . 2 7}$ \\
PastDue & -0.05 & -0.04 & $\mathbf{- 0 . 1 5}$ & $\mathbf{- 0 . 1 5}$ & $\mathbf{- 0 . 1 4}$ & $\mathbf{- 0 . 2 7}$ & $\mathbf{0 . 1 4}$ & & $\mathbf{0 . 6 5}$ \\
NonAccr & -0.01 & $\mathbf{0 . 0 9}$ & -0.07 & $\mathbf{- 0 . 2 0}$ & $\mathbf{- 0 . 2 0}$ & $\mathbf{- 0 . 2 4}$ & $\mathbf{0 . 3 2}$ & $\mathbf{0 . 6 3}$ & \\
\hline
\end{tabular}

Note: See variable definitions in Appendix 1. In Panel B, Pearson (Spearman) correlations are reported below (above) the diagonal. Correlations that are statistically significant at the 1 percent level are in boldface. 
Table 3

Is the Parent-only Leverage Associated with the CDS Premium?-Levels Regressions

Model 1: $C D S P_{a d j}=\mathrm{a}_{0}+\mathrm{a}_{1}$ CLev $+\mathrm{a}_{2}$ Spot $+\mathrm{a}_{3}$ StdRet $+\mathrm{a}_{4}$ PastDue $+\mathrm{a}_{5}$ NonAccr $+\varepsilon$

Model 2: $C D S P_{a d j}=\mathrm{b}_{0}+\mathrm{b}_{1}$ PLev $+\mathrm{b}_{2}$ Spot $+\mathrm{b}_{3}$ StdRet $+\mathrm{b}_{4}$ PastDue $+\mathrm{b}_{5}$ NonAccr $+\varepsilon$

Model 3: CDSP $a d j=\mathrm{c}_{0}+\mathrm{c}_{1}$ CLev $+\mathrm{c}_{2}$ PLev $+\mathrm{c}_{3}$ Spot $+\mathrm{c}_{4}$ StdRet $+\mathrm{c}_{5}$ PastDue $+\mathrm{c}_{6}$ NonAccr $+\varepsilon$

\begin{tabular}{|c|c|c|c|c|c|c|}
\hline & \multicolumn{3}{|c|}{$\begin{array}{l}1^{\text {st }} \text { Set of Leverage Measures } \\
C L e v=C L e v 1 \text { and } P \text { Lev }=\text { PLev } 1\end{array}$} & \multicolumn{3}{|c|}{$\begin{array}{l}2^{\text {nd }} \text { Set of Leverage Measures } \\
C L e v=C L e v 2 \text { and } P L e v=P L e v 2\end{array}$} \\
\hline & $\begin{array}{c}\text { (1) } \\
\text { Model } 1\end{array}$ & $\begin{array}{c}(2) \\
\text { Model } 2\end{array}$ & $\begin{array}{c}(3) \\
\text { Model } 3 \\
\end{array}$ & $\begin{array}{c}\text { (4) } \\
\text { Model } 1 \\
\end{array}$ & $\begin{array}{c}5) \\
\text { Model } 2 \\
\end{array}$ & $\begin{array}{c}(6) \\
\text { Model } 3 \\
\end{array}$ \\
\hline CLev & $\begin{array}{c}0.480^{* *} \\
(2.15)\end{array}$ & & $\begin{array}{l}0.073 \\
(0.33)\end{array}$ & $\begin{array}{c}0.767 * * \\
(2.63)\end{array}$ & & $\begin{array}{l}0.356 \\
(1.00)\end{array}$ \\
\hline PLev & & $\begin{array}{l}0.623 * * * \\
(4.37)\end{array}$ & $\begin{array}{l}0.581 * * * \\
(4.10)\end{array}$ & & $\begin{array}{l}0.735 * * * \\
(4.19)\end{array}$ & $\begin{array}{c}0.527^{* *} \\
(2.65)\end{array}$ \\
\hline Spot & $\begin{array}{c}-0.063 * * * \\
(-3.83)\end{array}$ & $\begin{array}{c}-0.039 * * \\
(-2.51)\end{array}$ & $\begin{array}{c}-0.041^{* *} \\
(-2.57)\end{array}$ & $\begin{array}{c}-0.052 * * * \\
(-3.86)\end{array}$ & $\begin{array}{c}-0.036^{* *} \\
(-2.29)\end{array}$ & $\begin{array}{c}-0.039^{* *} \\
(-2.44)\end{array}$ \\
\hline StdRet & $\begin{array}{l}10.916^{* * *} \\
(7.91)\end{array}$ & $\begin{array}{l}10.430 * * * \\
(8.26)\end{array}$ & $\begin{array}{l}10.438^{* * * *} \\
(8.35)\end{array}$ & $\begin{array}{l}10.670 * * * \\
(7.83)\end{array}$ & $\begin{array}{l}10.423 * * * \\
(8.43)\end{array}$ & $\begin{array}{l}10.414 * * * \\
(8.31)\end{array}$ \\
\hline PastDue & $\begin{array}{l}0.248 \\
(0.04)\end{array}$ & $\begin{array}{l}-0.499 \\
(-0.09)\end{array}$ & $\begin{array}{l}-0.278 \\
(-0.05)\end{array}$ & $\begin{array}{l}2.900 \\
(0.51)\end{array}$ & $\begin{array}{l}-0.238 \\
(-0.05)\end{array}$ & $\begin{array}{l}1.397 \\
(0.27)\end{array}$ \\
\hline NonAccr & $\begin{array}{l}5.057 \\
(0.86)\end{array}$ & $\begin{array}{l}12.047 * * \\
(2.14)\end{array}$ & $\begin{array}{l}11.318^{* *} \\
(2.05)\end{array}$ & $\begin{array}{l}7.136 \\
(1.32)\end{array}$ & $\begin{array}{l}12.201^{* *} \\
(2.21)\end{array}$ & $\begin{array}{c}10.647^{*} \\
(1.96)\end{array}$ \\
\hline Constant & $\begin{array}{l}-0.266^{*} \\
(-1.90)\end{array}$ & $\begin{array}{c}-0.187 * * \\
(-2.14)\end{array}$ & $\begin{array}{l}-0.216 \\
(-1.59)\end{array}$ & $\begin{array}{l}-0.165^{*} \\
(-1.84)\end{array}$ & $\begin{array}{c}-0.194 * * \\
(-2.24)\end{array}$ & $\begin{array}{c}-0.219 * * \\
(-2.47)\end{array}$ \\
\hline $\begin{array}{l}\text { Adj. } R^{2} \\
N\end{array}$ & $\begin{array}{c}35.8 \% \\
932\end{array}$ & $\begin{array}{c}39.4 \% \\
932\end{array}$ & $\begin{array}{c}39.4 \% \\
932\end{array}$ & $\begin{array}{c}38.0 \% \\
932\end{array}$ & $\begin{array}{c}39.3 \% \\
932\end{array}$ & $\begin{array}{c}39.9 \% \\
932\end{array}$ \\
\hline $\begin{array}{l}\text { Vuong Test } \\
\text { Z-Stat } \\
P \text {-value }\end{array}$ & $\begin{array}{r}\text { Model } \\
-1 \\
0 \\
\end{array}$ & $\begin{array}{l}1 \text { vs. } 2 \\
6 \\
5 \\
\end{array}$ & & $\begin{array}{r}\text { Model } \\
-2.5 \\
0\end{array}$ & $\begin{array}{l}1 \text { vs. } 2 \\
* * \\
1 \\
\end{array}$ & \\
\hline
\end{tabular}

Note: The leverage variables, CLev and PLev, in the models are general labels. In Columns 1-3, we use the first leverage measurement for the variables. In Columns 4-6, we use the second leverage measurement. See variable definitions in Appendix 1. We estimate the models using the robust-regression method, which uses iterative estimations and is robust to influential observations, with the standard errors clustered by firm and robust to heteroscedasticity (see Leone et al. 2019). $t$-statistics are reported in parentheses. ${ }^{* *}$, **, and * indicate significance at the $1 \%, 5 \%$, and $10 \%$ levels, respectively. 
Table 4

Is the Parent-only Leverage Associated with the CDS Premium? - Changes Regressions

Model 4: $\Delta C D S P_{a d j}=\mathrm{d}_{0}+\mathrm{d}_{1} \Delta C L e v+\mathrm{d}_{2} \Delta S p o t+\mathrm{d}_{3} \Delta S t d R e t+\mathrm{d}_{4} \Delta$ PastDue $+\mathrm{d}_{5} \Delta N o n A c c r+\varepsilon$

Model 5: $\Delta C D S P_{a d j}=\mathrm{e}_{0}+\mathrm{e}_{1} \Delta P L e v+\mathrm{e}_{2} \Delta S p o t+\mathrm{e}_{3} \Delta S t d R e t+\mathrm{e}_{4} \Delta P a s t D u e+\mathrm{e}_{5} \Delta N o n A c c r+\varepsilon$

Model 6: $\Delta C D S P_{a d j}=\mathrm{f}_{0}+\mathrm{f}_{1} \Delta C L e v+\mathrm{f}_{2} \Delta$ PLev $+\mathrm{f}_{3} \Delta S p o t+\mathrm{f}_{4} \Delta S t d R e t+\mathrm{f}_{5} \Delta$ PastDue $+\mathrm{f}_{6} \Delta N o n A c c r+\varepsilon$

\begin{tabular}{|c|c|c|c|c|c|c|}
\hline & \multicolumn{3}{|c|}{$\begin{array}{c}1{ }^{\text {st }} \text { Set of Leverage Measures } \\
\Delta C L e v=\Delta C L e v 1 \text { and } \triangle P L e v=\Delta P \text { Lev } 1\end{array}$} & \multicolumn{3}{|c|}{$\begin{array}{c}2^{\text {nd }} \text { Set of Leverage Measures } \\
\Delta C L e v=\Delta C L e v 2 \text { and } \triangle P L e v=\Delta P \text { Lev } 2\end{array}$} \\
\hline & $\begin{array}{c}\text { (1) } \\
\text { Model } 4\end{array}$ & $\begin{array}{c}(2) \\
\text { Model } 5\end{array}$ & $\begin{array}{c}(3) \\
\text { Model } 6\end{array}$ & $\begin{array}{c}(4) \\
\text { Model } 4\end{array}$ & $\begin{array}{c}(5) \\
\text { Model } 5\end{array}$ & $\begin{array}{c}(6) \\
\text { Model } 6\end{array}$ \\
\hline$\Delta C L e v$ & $\begin{array}{l}0.373^{* *} \\
(2.32)\end{array}$ & & $\begin{array}{l}0.258 \\
(1.62)\end{array}$ & $\begin{array}{l}0.588 \\
(1.67)\end{array}$ & & $\begin{array}{l}0.439 \\
(1.44)\end{array}$ \\
\hline$\triangle P L e v$ & & $\begin{array}{c}0.611 * * \\
(2.53)\end{array}$ & $\begin{array}{c}0.528^{* *} \\
(2.29)\end{array}$ & & $\begin{array}{l}0.773 * * * \\
(3.77)\end{array}$ & $\begin{array}{l}0.705^{* * *} \\
(3.85)\end{array}$ \\
\hline$\Delta$ Spot & $\begin{array}{l}-0.023 \\
(-1.70)\end{array}$ & $\begin{array}{r}-0.024^{*} \\
(-1.77)\end{array}$ & $\begin{array}{c}-0.025^{*} \\
(-1.81)\end{array}$ & $\begin{array}{l}-0.021 \\
(-1.56)\end{array}$ & $\begin{array}{l}-0.020 \\
(-1.46)\end{array}$ & $\begin{array}{l}-0.022 \\
(-1.59)\end{array}$ \\
\hline$\Delta S t d R e t$ & $\begin{array}{c}-2.483 * * * \\
(-3.60)\end{array}$ & $\begin{array}{c}-2.422 * * * \\
(-3.69)\end{array}$ & $\begin{array}{c}-2.513 * * * \\
(-3.72)\end{array}$ & $\begin{array}{c}-2.394 * * * \\
(-3.56)\end{array}$ & $\begin{array}{c}-2.383 * * * \\
(-3.61)\end{array}$ & $\begin{array}{c}-2.426 * * * \\
(-3.61)\end{array}$ \\
\hline$\Delta$ PastDue & $\begin{array}{l}-7.242 \\
(-0.94)\end{array}$ & $\begin{array}{l}-7.078 \\
(-0.92)\end{array}$ & $\begin{array}{l}-7.368 \\
(-0.97)\end{array}$ & $\begin{array}{l}-8.434 \\
(-1.07)\end{array}$ & $\begin{array}{l}-8.431 \\
(-1.09)\end{array}$ & $\begin{array}{l}-8.595 \\
(-1.12)\end{array}$ \\
\hline$\Delta$ NonAccr & $\begin{array}{l}9.269 * * * \\
(2.85)\end{array}$ & $\begin{array}{l}9.246 * * \\
(2.60)\end{array}$ & $\begin{array}{c}9.399 * * \\
(2.71)\end{array}$ & $\begin{array}{c}9.194 * * \\
(2.76)\end{array}$ & $\begin{array}{c}9.712 * * \\
(2.67)\end{array}$ & $\begin{array}{c}9.586 * * \\
(2.69)\end{array}$ \\
\hline Constant & $\begin{array}{l}-0.008 \\
(-1.45)\end{array}$ & $\begin{array}{l}-0.009 \\
(-1.64)\end{array}$ & $\begin{array}{l}-0.008 \\
(-1.54)\end{array}$ & $\begin{array}{l}-0.008 \\
(-1.52)\end{array}$ & $\begin{array}{c}-0.009^{*} \\
(-1.75)\end{array}$ & $\begin{array}{l}-0.008 \\
(-1.65)\end{array}$ \\
\hline $\begin{array}{l}\text { Adj. } \mathrm{R}^{2} \\
\mathrm{~N}\end{array}$ & $\begin{array}{c}2.6 \% \\
844\end{array}$ & $\begin{array}{c}3.0 \% \\
844\end{array}$ & $\begin{array}{c}3.1 \% \\
844\end{array}$ & $\begin{array}{c}2.5 \% \\
844\end{array}$ & $\begin{array}{c}3.2 \% \\
844\end{array}$ & $\begin{array}{c}3.3 \% \\
844\end{array}$ \\
\hline $\begin{array}{l}\text { Vuong Test } \\
\text { Z-Stat } \\
P \text {-value }\end{array}$ & $\begin{array}{r}\text { Mode } \\
-0 \\
0\end{array}$ & $\begin{array}{l}\text { t vs. } 5 \\
4 \\
1\end{array}$ & & $\begin{array}{r}\text { Mode } \\
-0\end{array}$ & $\begin{array}{l}\text { t vs. } 5 \\
5 \\
4\end{array}$ & \\
\hline
\end{tabular}

Note: A change variable is the difference between the level variable measured for fiscal quarter $t$ and that measured for fiscal quarter $t-1$. See definitions of the level variables in Appendix 1. The leverage variables in the models are general labels. In Columns 1-3, we use the first leverage measurement for the variables. In Columns 4-6, we use the second leverage measurement. The number of observations decreases from 932 in Table 3 to 844 in this table after we drop 48 (31) observations for which lagged leverage (lagged CDS premium) is unavailable and 9 observations for which CDS contracts use MR for fiscal quarter $t-1$ and XR for fiscal quarter $t$ around the CDS Big Bang. We estimate the models using the robust-regression method, which uses iterative estimations and is robust to influential observations, with the standard errors clustered by firm and robust to heteroscedasticity (see Leone et al. 2019). $t$-statistics are reported in parentheses. ***, $* *$, and * indicate significance at the $1 \%, 5 \%$, and $10 \%$ levels, respectively. 
Table 5

\section{Additional Controls}

Panel A: Controlling for earnings performance

Model: $C D S P_{a d j}=\mathrm{c}_{0}+\mathrm{c}_{1}$ CLev $+\mathrm{c}_{2} P$ Lev $+\mathrm{c}_{3}$ Spot $+\mathrm{c}_{4}$ StdRet $+\mathrm{c}_{5}$ PastDue $+\mathrm{c}_{6}$ NonAccr $+\mathrm{c}_{7}$ Size $+\mathrm{c}_{7} R O A+\varepsilon$

\begin{tabular}{|c|c|c|c|c|c|}
\hline$Y=C D S P_{a d j}$ & $(1)$ & $(2)$ & $Y=C D S P_{a d j}$ & (3) & $(4)$ \\
\hline CLevl & $\begin{array}{l}0.218 \\
(1.19)\end{array}$ & $\begin{array}{l}0.085 \\
(0.41)\end{array}$ & CLev2 & $\begin{array}{c}0.581 * * \\
(2.30)\end{array}$ & $\begin{array}{l}0.340 \\
(1.01)\end{array}$ \\
\hline PLevl & $\begin{array}{c}0.694 * * * \\
(4.80)\end{array}$ & $\begin{array}{c}0.796 * * * \\
(4.81)\end{array}$ & PLev2 & $\begin{array}{c}0.534^{* *} \\
(2.52)\end{array}$ & $\begin{array}{c}0.657^{* *} \\
(2.31)\end{array}$ \\
\hline Spot & $\begin{array}{c}-0.047 * * * \\
(-3.47)\end{array}$ & $\begin{array}{c}-0.040 * * \\
(-2.42)\end{array}$ & Spot & $\begin{array}{c}-0.039 * * * \\
(-2.95)\end{array}$ & $\begin{array}{c}-0.034 * * \\
(-2.06)\end{array}$ \\
\hline StdRet & $\begin{array}{c}7.390 * * * \\
(5.00)\end{array}$ & $\begin{array}{c}7.731 * * * \\
(5.49)\end{array}$ & StdRet & $\begin{array}{c}7.757 * * * \\
(5.60)\end{array}$ & $\begin{array}{c}7.601^{* * *} \\
(5.66)\end{array}$ \\
\hline PastDue & $\begin{array}{c}13.912^{* * *} \\
(2.49)\end{array}$ & $\begin{array}{l}8.715 \\
(1.40)\end{array}$ & PastDue & $\begin{array}{c}16.502 * * * \\
(2.94)\end{array}$ & $\begin{array}{l}9.924 \\
(1.60)\end{array}$ \\
\hline NonAccr & $\begin{array}{l}-1.557 \\
(-0.25)\end{array}$ & $\begin{array}{c}6.073 \\
(0.91)\end{array}$ & NonAccr & $\begin{array}{l}-2.530 \\
(-0.43)\end{array}$ & $\begin{array}{l}4.307 \\
(0.67)\end{array}$ \\
\hline Size & $\begin{array}{c}-0.093 * * * \\
(-2.95)\end{array}$ & $\begin{array}{c}-0.100 * * * \\
(-2.83)\end{array}$ & Size & $\begin{array}{c}-0.067 * * \\
(-2.22)\end{array}$ & $\begin{array}{c}-0.084 * * \\
(-2.31)\end{array}$ \\
\hline CROA & $\begin{array}{c}-56.520 * * * \\
(-4.12)\end{array}$ & & $C R O A$ & $\begin{array}{c}-67.836 * * * \\
(-4.87)\end{array}$ & \\
\hline PROA & & $\begin{array}{c}-3.414^{*} \\
(-1.86)\end{array}$ & PROA & & $\begin{array}{c}-6.100 * * * \\
(-3.03)\end{array}$ \\
\hline Constant & $\begin{array}{c}0.895^{* *} \\
(2.36)\end{array}$ & $\begin{array}{c}0.881^{* *} \\
(2.08)\end{array}$ & Constant & $\begin{array}{l}0.702^{*} \\
(2.00)\end{array}$ & $\begin{array}{c}0.801^{*} \\
(1.91)\end{array}$ \\
\hline Adj. $R^{2}$ & $45.6 \%$ & $41.9 \%$ & Adj. $\mathrm{R}^{2}$ & $47.8 \%$ & $42.5 \%$ \\
\hline $\mathrm{N}$ & 932 & 929 & $\mathrm{~N}$ & 932 & 929 \\
\hline
\end{tabular}


Table 5

(Continued)

Panel B: Controlling for liquidity risk

\begin{tabular}{|c|c|c|c|}
\hline$Y=C D S P_{a d j}$ & $(1)$ & $Y=C D S P_{a d j}$ & $(2)$ \\
\hline CLev1 & $\begin{array}{l}-0.044 \\
(-0.17)\end{array}$ & CLev2 & $\begin{array}{l}0.147 \\
(0.38)\end{array}$ \\
\hline PLev1 & $\begin{array}{c}1.015^{* * *} \\
(4.74)\end{array}$ & PLev2 & $\begin{array}{c}1.039 * * * \\
(3.10)\end{array}$ \\
\hline Spot & $\begin{array}{l}-0.031 \\
(-1.50)\end{array}$ & Spot & $\begin{array}{l}-0.029 \\
(-1.41)\end{array}$ \\
\hline StdRet & $\begin{array}{c}9.469 * * * \\
(6.58)\end{array}$ & StdRet & $\begin{array}{c}9.813 * * * \\
(7.33)\end{array}$ \\
\hline PastDue & $\begin{array}{l}7.226 \\
(1.26)\end{array}$ & PastDue & $\begin{array}{l}7.201 \\
(1.29)\end{array}$ \\
\hline NonAccr & $\begin{array}{l}7.170 \\
(1.21)\end{array}$ & NonAccr & $\begin{array}{l}6.727 \\
(1.17)\end{array}$ \\
\hline Depth & $\begin{array}{l}-0.013 \\
(-1.42)\end{array}$ & Depth & $\begin{array}{l}-0.012 \\
(-1.31)\end{array}$ \\
\hline Size & $\begin{array}{c}-0.077 * * \\
(-2.29)\end{array}$ & Size & $\begin{array}{c}-0.068^{*} \\
(-1.82)\end{array}$ \\
\hline Constant & $\begin{array}{l}0.637 \\
(1.57)\end{array}$ & Constant & $\begin{array}{l}0.504 \\
(1.18)\end{array}$ \\
\hline $\begin{array}{l}\text { Adj. } R^{2} \\
N\end{array}$ & $\begin{array}{c}41.0 \% \\
914\end{array}$ & $\begin{array}{l}\text { Adj. } \mathrm{R}^{2} \\
\mathrm{~N}\end{array}$ & $\begin{array}{c}40.7 \% \\
914\end{array}$ \\
\hline
\end{tabular}

Note: The leverage variables in the models are general labels and we use either the set of CLev1 and PLev1 or the set of CLev2 and PLev2 in the estimations. ROA in the model is a general label and we use either $C R O A$ or $P R O A$ in the estimations. In Panel A, CROA is measured as consolidated earnings before extraordinary items divided by consolidated total assets for fiscal quarter $t$. PROA is measured as parentonly net income divided by parent-only total assets for fiscal quarter $t$. Three observations are lost when PROA is used because banks report year-to-date income in FR Y-9LP reports, so we need both the laggedand current-quarter FR Y-9LP reports to calculate PROA. In Panel B, Size and Depth capture the liquidity risk of CDS. The number of observations decreases from 932 in Table 3 to 914 after we drop 18 observations with missing Depth. See variable definitions in Appendix 1. We estimate the models using the robust-regression method, which uses iterative estimations and is robust to influential observations, with the standard errors clustered by firm and robust to heteroscedasticity (see Leone et al. 2019). $t$-statistics are reported in parentheses. $* * * * *$, and $*$ indicate significance at the $1 \%, 5 \%$, and $10 \%$ levels, respectively. 
Table 6

Is the Parent-only Leverage Associated with Bond Spreads at Bond Issuance?

Panel A: Summary statistics

\begin{tabular}{lcccccc}
\hline & $\mathrm{N}$ & Mean & Std. dev. & P25 & Median & P75 \\
BondSpread & 3,569 & 118.61 & 120.10 & 60.00 & 95.00 & 147.00 \\
CLev1 & 3,569 & 0.72 & 0.13 & 0.66 & 0.75 & 0.82 \\
CLev2 & 3,569 & 0.28 & 0.14 & 0.19 & 0.25 & 0.32 \\
PLev1 & 3,569 & 0.36 & 0.20 & 0.23 & 0.35 & 0.48 \\
PLev2 & 3,569 & 0.29 & 0.17 & 0.19 & 0.29 & 0.39 \\
Size & 3,569 & 10.97 & 11.21 & 1.20 & 10.38 & 11.88 \\
MTB & 3,569 & 1.05 & 0.09 & 0.99 & 1.03 & 1.07 \\
InvGrade & 3,569 & 0.97 & 0.16 & 1.00 & 1.00 & 1.00 \\
Amount & 3,569 & 318.71 & 522.78 & 25.00 & 98.80 & 385.00 \\
Log(Amount) & 3,569 & 4.43 & 1.98 & 3.22 & 4.59 & 5.95 \\
Maturity & 3,569 & 168.35 & 141.75 & 60.87 & 121.77 & 365.30 \\
Log(Maturity) & 3,569 & 4.67 & 1.05 & 4.11 & 4.80 & 5.90 \\
Secured & 3,569 & 0.40 & 0.49 & 0 & 0 & 1 \\
\hline
\end{tabular}

Panel B: Pairwise correlations

\begin{tabular}{lccccccccccc}
\hline & 1 & 2 & 3 & 4 & 5 & 6 & 7 & 8 & 9 & 10 & 11 \\
1. BondSpread & & $\mathbf{0 . 1 1}$ & $\mathbf{0 . 1 4}$ & $\mathbf{0 . 2 3}$ & $\mathbf{0 . 2 4}$ & $\mathbf{0 . 1 2}$ & $\mathbf{- 0 . 3 1}$ & $\mathbf{- 0 . 1 7}$ & $\mathbf{0 . 0 7}$ & $\mathbf{0 . 3 6}$ & $\mathbf{0 . 1 4}$ \\
2. CLev1 & $\mathbf{0 . 0 8}$ & & $\mathbf{0 . 9 4}$ & $\mathbf{0 . 7 6}$ & $\mathbf{0 . 7 1}$ & -0.01 & $\mathbf{- 0 . 2 1}$ & $\mathbf{- 0 . 1 0}$ & $\mathbf{- 0 . 2 4}$ & $\mathbf{0 . 0 8}$ & $\mathbf{0 . 1 1}$ \\
3. CLev2 & $\mathbf{0 . 1 7}$ & $\mathbf{0 . 8 3}$ & & $\mathbf{0 . 7 3}$ & $\mathbf{0 . 7 0}$ & -0.01 & $\mathbf{- 0 . 2 6}$ & $\mathbf{- 0 . 1 0}$ & $\mathbf{- 0 . 1 5}$ & $\mathbf{0 . 0 7}$ & $\mathbf{0 . 1 7}$ \\
4. PLev1 & $\mathbf{0 . 1 9}$ & $\mathbf{0 . 6 7}$ & $\mathbf{0 . 7 5}$ & & $\mathbf{0 . 9 9}$ & $\mathbf{0 . 3 4}$ & $\mathbf{- 0 . 4 8}$ & $\mathbf{- 0 . 0 7}$ & $\mathbf{- 0 . 0 7}$ & $\mathbf{0 . 3 1}$ & $\mathbf{0 . 3 3}$ \\
5. PLev2 & $\mathbf{0 . 2 0}$ & $\mathbf{0 . 6 4}$ & $\mathbf{0 . 7 5}$ & $\mathbf{0 . 9 9}$ & & $\mathbf{0 . 3 7}$ & $\mathbf{- 0 . 5 1}$ & $\mathbf{- 0 . 0 7}$ & -0.02 & $\mathbf{0 . 3 3}$ & $\mathbf{0 . 3 6}$ \\
6. Size & 0.03 & $\mathbf{0 . 1 8}$ & $\mathbf{0 . 0 8}$ & $\mathbf{0 . 4 6}$ & $\mathbf{0 . 4 6}$ & & $\mathbf{- 0 . 1 3}$ & 0.01 & 0.00 & $\mathbf{0 . 4 4}$ & $\mathbf{0 . 3 4}$ \\
7. MTB & $\mathbf{- 0 . 1 6}$ & $\mathbf{- 0 . 2 3}$ & $\mathbf{- 0 . 2 3}$ & $\mathbf{- 0 . 4 0}$ & $\mathbf{- 0 . 4 0}$ & $\mathbf{- 0 . 1 5}$ & & 0.03 & $\mathbf{- 0 . 2 1}$ & $\mathbf{- 0 . 2 8}$ & $\mathbf{- 0 . 3 9}$ \\
8. InvGrade & $\mathbf{- 0 . 3 9}$ & $\mathbf{- 0 . 0 8}$ & $\mathbf{- 0 . 0 7}$ & $\mathbf{- 0 . 0 7}$ & $\mathbf{- 0 . 0 6}$ & 0.01 & 0.01 & & $\mathbf{0 . 0 8}$ & $\mathbf{- 0 . 0 5}$ & $\mathbf{- 0 . 0 8}$ \\
9. Log(Amount) & 0.03 & $\mathbf{- 0 . 2 5}$ & $\mathbf{- 0 . 0 5}$ & $\mathbf{- 0 . 0 5}$ & 0.00 & 0.02 & $\mathbf{- 0 . 1 1}$ & $\mathbf{0 . 0 7}$ & & $\mathbf{- 0 . 1 1}$ & $\mathbf{- 0 . 1 4}$ \\
10. Log(Maturity) & $\mathbf{0 . 2 2}$ & $\mathbf{0 . 1 1}$ & $\mathbf{0 . 1 2}$ & $\mathbf{0 . 3 6}$ & $\mathbf{0 . 3 7}$ & $\mathbf{0 . 4 1}$ & $\mathbf{- 0 . 3 0}$ & $\mathbf{- 0 . 0 6}$ & $\mathbf{- 0 . 0 8}$ & & $\mathbf{0 . 5 8}$ \\
11. Secured & $\mathbf{0 . 1 2}$ & $\mathbf{0 . 1 3}$ & $\mathbf{0 . 1 9}$ & $\mathbf{0 . 3 5}$ & $\mathbf{0 . 3 6}$ & $\mathbf{0 . 3 1}$ & $\mathbf{- 0 . 2 6}$ & $\mathbf{- 0 . 0 8}$ & $\mathbf{- 0 . 0 6}$ & $\mathbf{0 . 5 6}$ & \\
\hline
\end{tabular}


Panel C: Regression results

Model 7: BondSpread $=\mathrm{g}_{0}+\mathrm{g}_{1}$ CLev $+\mathrm{g}_{2}$ Size $+\mathrm{g}_{3}$ MTB $+\mathrm{g}_{4}$ InvGrade $+\mathrm{g}_{5} \log$ (Amount)

$+\mathrm{g}_{6} \log$ (Maturity) $+\mathrm{g}_{7}$ Secured $+\varepsilon$

Model 8: BondSpread $=\mathrm{j}_{0}+\mathrm{j}_{1}$ PLev $+\mathrm{j}_{2}$ Size $+\mathrm{j}_{3} M T B+\mathrm{j}_{4}$ InvGrade $+\mathrm{j}_{5} \log$ (Amount)

$+\mathrm{j}_{6} \log$ (Maturity) $+\mathrm{j}_{7}$ Secured $+\varepsilon$

Model 9: BondSpread $=\mathrm{k}_{0}+\mathrm{k}_{1}$ CLev $+\mathrm{k}_{2}$ PLev $+\mathrm{k}_{3}$ Size $+\mathrm{k}_{4} M T B+\mathrm{k}_{5}$ InvGrade

$+\mathrm{k}_{6} \log$ (Amount) $+\mathrm{k}_{7} \log \left(\right.$ Maturity) $+\mathrm{k}_{8}$ Secured $+\varepsilon$

\begin{tabular}{|c|c|c|c|c|c|c|}
\hline & \multicolumn{3}{|c|}{$\begin{array}{c}1^{\text {st }} \text { Set of Leverage Measures } \\
C L e v=C L e v 1 \text { and } P L e v=P L e v 1\end{array}$} & \multicolumn{3}{|c|}{$\begin{array}{l}2^{\text {nd }} \text { Set of Leverage Measures } \\
C L e v=C L e v 2 \text { and } P L e v=P \text { Lev } 2\end{array}$} \\
\hline & $\begin{array}{c}(1) \\
\text { Model } 7 \\
\end{array}$ & $\begin{array}{c}(2) \\
\text { Model } 8\end{array}$ & $\begin{array}{c}(3) \\
\text { Model } 9\end{array}$ & $\begin{array}{c}(4) \\
\text { Model } 7\end{array}$ & $\begin{array}{c}(5) \\
\text { Model } 8\end{array}$ & $\begin{array}{c}(6) \\
\text { Model } 9\end{array}$ \\
\hline CLev & $\begin{array}{c}38.943 * \\
(1.92)\end{array}$ & & $\begin{array}{l}-21.020 \\
(-1.25)\end{array}$ & $\begin{array}{l}79.359 * * * \\
(5.34)\end{array}$ & & $\begin{array}{l}43.953 * * \\
(2.16)\end{array}$ \\
\hline PLev & & $\begin{array}{c}57.401 * * * \\
(4.09)\end{array}$ & $\begin{array}{c}67.573^{* * * *} \\
(4.22)\end{array}$ & & $\begin{array}{c}74.113 * * * \\
(4.30)\end{array}$ & $\begin{array}{c}41.623 * * \\
(2.05)\end{array}$ \\
\hline Size & $\begin{array}{c}-2.894 * * \\
(-2.64)\end{array}$ & $\begin{array}{c}-5.718 * * * \\
(-3.66)\end{array}$ & $\begin{array}{c}-5.991 * * * \\
(-3.98)\end{array}$ & $\begin{array}{l}-1.850 \\
(-1.34)\end{array}$ & $\begin{array}{c}-5.665^{* * * *} \\
(-3.52)\end{array}$ & $\begin{array}{c}-3.975 * * \\
(-2.03)\end{array}$ \\
\hline$M T B$ & $\begin{array}{c}-101.619 * * \\
(-2.51)\end{array}$ & $\begin{array}{c}-76.208 * * \\
(-2.27)\end{array}$ & $\begin{array}{c}-76.709 * * \\
(-2.44)\end{array}$ & $\begin{array}{c}-93.218 * * * \\
(-2.69)\end{array}$ & $\begin{array}{c}-76.542 * * \\
(-2.37)\end{array}$ & $\begin{array}{c}-80.960 * * \\
(-2.48)\end{array}$ \\
\hline InvGrade & $\begin{array}{c}-163.777 * * * \\
(-11.02)\end{array}$ & $\begin{array}{c}-160.205^{* * *} \\
(-11.47)\end{array}$ & $\begin{array}{c}-160.544 * * * \\
(-11.60)\end{array}$ & $\begin{array}{c}-159.416 * * * \\
(-10.84)\end{array}$ & $\begin{array}{c}-158.978 * * * \\
(-11.33)\end{array}$ & $\begin{array}{c}-158.436 * * * \\
(-11.03)\end{array}$ \\
\hline $\log ($ Amount $)$ & $\begin{array}{c}4.723 * * * \\
(6.71)\end{array}$ & $\begin{array}{c}4.459 * * * \\
(6.33)\end{array}$ & $\begin{array}{c}4.135 * * * \\
(5.48)\end{array}$ & $\begin{array}{c}4.389 * * * \\
(7.75)\end{array}$ & $\begin{array}{c}4.141 * * * \\
(5.39)\end{array}$ & $\begin{array}{c}4.300^{* * *} \\
(6.38)\end{array}$ \\
\hline Log(Maturity) & $\begin{array}{c}31.405^{* * *} \\
(12.00)\end{array}$ & $\begin{array}{c}30.640 * * * \\
(12.98)\end{array}$ & $\begin{array}{c}30.364 * * * \\
(12.62)\end{array}$ & $\begin{array}{c}31.191^{* * *} \\
(12.85)\end{array}$ & $\begin{array}{c}30.443 * * * \\
(13.38)\end{array}$ & $\begin{array}{c}30.809 * * * \\
(13.27)\end{array}$ \\
\hline Secured & $\begin{array}{c}-31.472 * * * \\
(-6.08)\end{array}$ & $\begin{array}{c}-34.242 * * * \\
(-5.65)\end{array}$ & $\begin{array}{c}-34.597 * * * \\
(-5.71)\end{array}$ & $\begin{array}{c}-34.648 * * * \\
(-6.14)\end{array}$ & $\begin{array}{c}-35.414 * * * \\
(-5.71)\end{array}$ & $\begin{array}{c}-35.448 * * * \\
(-5.93)\end{array}$ \\
\hline Constant & $\begin{array}{c}210.509 * * * \\
\quad(4.07)\end{array}$ & $\begin{array}{c}224.824 * * * \\
(4.91)\end{array}$ & $\begin{array}{c}243.067 * * * \\
(5.38)\end{array}$ & $\begin{array}{c}196.298 * * * \\
(4.03)\end{array}$ & $\begin{array}{c}225.092 * * * \\
(5.14)\end{array}$ & $\begin{array}{c}205.771 * * * \\
\quad(4.32)\end{array}$ \\
\hline $\begin{array}{l}\text { Adj. } R^{2} \\
N\end{array}$ & $\begin{array}{c}41.8 \% \\
3,569\end{array}$ & $\begin{array}{c}43.8 \% \\
3,569\end{array}$ & $\begin{array}{c}43.9 \% \\
3,569\end{array}$ & $\begin{array}{c}44.3 \% \\
3,569\end{array}$ & $\begin{array}{l}44.3 \% \\
3,569\end{array}$ & $\begin{array}{c}44.7 \% \\
3,569\end{array}$ \\
\hline $\begin{array}{l}\text { Vuong Test } \\
\text { Z-Stat } \\
P \text {-value }\end{array}$ & $\begin{array}{r}\text { Models } \\
-2.5 \\
0 . \\
\end{array}$ & $\begin{array}{l}7 \text { vs. } 8 \\
6 * * \\
01 \\
\end{array}$ & & $\begin{array}{r}\text { Models } \\
0 . \\
0 .\end{array}$ & $\begin{array}{l}7 \text { vs. } 8 \\
01 \\
99\end{array}$ & \\
\hline
\end{tabular}

Note: The leverage variables, CLev and PLev, in the models are general labels. In Panel C, we use the first leverage measurement for the variables in Columns 1-3 and the second leverage measurement in Columns 4-6. See variable definitions in Appendix 1 except that the leverage variables and Size are now measured at the end of the most recent quarter before bond issuance. The robust regression method uses iterative estimations and is robust to influential observations. Standard errors are clustered by firm and robust to heteroscedasticity. $t$-statistics are reported in parentheses. $* * *, * *$, and $*$ indicate significance at the $1 \%$, $5 \%$, and $10 \%$ levels, respectively. 